\title{
Regional ecosystem dynamics in the ACC: simulations with a three-dimensional ocean-plankton model
}

\author{
Inga Hense*, Ralph Timmermann ${ }^{1}$, Aike Beckmann, Ulrich V. Bathmann \\ Alfred Wegener Institute for Polar and Marine Research, Bremerhaven, Germany
}

Received 2 September 2002; accepted 6 March 2003

\begin{abstract}
Within the high nutrient-low chlorophyll regime of the Antarctic Circumpolar Current (ACC), high phytoplankton concentrations are frequently observed in the vicinity of the Antarctic Polar Front (APF). As is typical for frontal systems, hydrography in this region is characterized by meanders and eddies as well as up- and downwelling cells which redistribute nutrients and influence the depth of the euphotic zone.

To study the processes leading to the observed phytoplankton distribution, a coupled ocean-plankton model for ecosystem studies in the ACC has been developed. The ocean component is an eddy-resolving version of the s-Coordinate Primitive Equation Model (SPEM). The model has a horizontal resolution of $1 / 12^{\circ}$ and a vertical resolution increased near the surface. The biological model (BIMAP) comprises two biogeochemical cycles - silica and nitrogen - and a prognostic iron compartment to include possible effects of micronutrient limitation.

Model results indicate that part of the ecosystem's regional variability can be attributed to the effect of vertical and horizontal advection. However, frontal dynamics alone cannot explain the observed enhanced concentrations of phytoplankton biomass near the APF and the minima in the northern and southern ACC. Only when iron limitation is taken into account, the model simulates plankton concentrations in close agreement with observations during the SO-JGOFS cruises. While in the northern ACC phytoplankton growth is limited by silicate, primary production is limited by iron south of the APF. Near the APF, mesoscale iron upwelling enhances primary production, leading to increased phyto- and zooplankton biomass. The meridional structure with two plankton maxima is closely linked to the cross-front overturning circulation. This double-cell circulation with two upwelling branches is caused by the northward sloping large-scale bottom topography.
\end{abstract}

(c) 2003 Elsevier B.V. All rights reserved.

Keywords: Antarctic Polar Front; Ocean-plankton model; Phytoplankton distribution; Iron limitation

* Corresponding author. Present address: Finnish Institute for Marine Research, Lyypekinkuja 3A, P.O. Box 33, FIN-00931 Helsinki, Finland.

E-mail address: Inga.Hense@fimr.fi (I. Hense).

${ }^{1}$ Present address: Institut d'Astronomie et de Géophysique G. Lemaître, Université Catholique de Louvain, Louvain-la-Neuve, Belgium.

\section{Introduction}

After the Discovery cruises of 1929-1931 in the southwest Atlantic and the Bellingshausen Sea, Hart (1934) pointed out the discrepancy between the high stock of nutrients and low abundance of phytoplankton, and suggested that trace elements like iron could be responsible for the low phytoplankton stock. Since 
1934, the reasons for the so-called "Antarctic Paradox" are a matter of debate and several hypotheses about the "mystery" high nutrient-low chlorophyll (HNLC) area in the Southern Ocean have been put forward. Otherwise, satellite images (Sullivan et al., 1993; Stramski et al., 1999) and observations during field studies (e.g. Bathmann et al., 1997a) distinguish the region of the Antarctic Polar Front as an area with higher phytoplankton stocks compared to the surrounding HNLC water, leading to the question about the dominant factors controlling the development of phytoplankton blooms.

One group of hypotheses suggests that the special hydrographic conditions at the Antarctic Polar Front are responsible for the observed enhancement of primary production. The Antarctic Polar Front (APF) is located in the center of the Antarctic Circumpolar Current (ACC), which is the earth's only closed zonal oceanic current system (Burkov, 1993). The APF was first termed by Wyrtki (1960) who renamed the former expression of the Antarctic Convergence. Since then, several definitions of the Antarctic Polar Front have been specified (see review of Belkin and Gordon, 1996); the most common defines the APF as the northernmost extent of the subsurface $2{ }^{\circ} \mathrm{C}$ isotherme (Botnikov, 1963). The position of the front is influenced by local bathymetry (e.g. Trathan et al., 1997) and may vary due to fluctuations of the surface wind stress (e.g. Smith and Fandry, 1978).

At the APF, relatively warm water from the north meets colder water from the south which is subducted due to the large-scale convergence and contributes to the formation of the Antarctic Intermediate Water. This process, however, occurs on much longer time scales than those important for plankton dynamics. As sharp meridional gradients of temperature and salinity are found down to the bottom, the APF has a pronounced expression throughout the water column (Gouretski and Danilov, 1994). The strong horizontal density gradient leads to baroclinic instability which in some regions is triggered by local bottom topography (Chelton et al., 1990; Veth et al., 1997). As a consequence, meandering currents establish and isolated eddies are formed. Warm or cold core eddies (or rings) on either side of the front are frequently observed (Ikeda et al., 1989; Gouretski and Danilov, 1994). Eddies are often assumed to promote phytoplankton growth as they contribute to cross frontal and vertical nutrient exchange (e.g. Pingree et al., 1979; Flierl and Davis, 1993). However, enhanced phytoplankton biomass in the vicinity of the Antarctic Polar Front is also observed outside of eddies.

Other authors suggest that the mixed layer depth is influenced by mesoscale frontal dynamics. Strass et al. (2002a) hypothesize that cross-frontal circulation leads to a shallow mixed layer not only in the upwelling areas but also directly above the front. Light limitation due to a deep mixed layer is discussed to be a dominant factor in controlling phytoplankton blooms in the Southern Ocean (e.g. Sakshaug and Holm-Hansen, 1984; Smith and Nelson, 1985; Mitchell et al., 1991), where the wind stress is extraordinarily strong compared to other regions of the world ocean (Wearn and Baker, 1981; Gille et al., 2001) and deep vertical mixing is observed; a shallow mixed layer near the front would thus promote net growth of phytoplankton biomass.

Another effect of frontal dynamics on phytoplankton growth in the Antarctic Polar Front is the vertical nutrient transport arising from up- and downwelling events in eddies or due to the meandering current. Mesoscale vertical velocities in frontal regions are in the range between $1 \mathrm{~m} /$ day and more than $100 \mathrm{~m} /$ day (Eriksen et al., 1991; Pollard and Regier, 1992; Strass, 1994) and therefore affect hydrography on time scales corresponding to those of phytoplankton growth. Consequently, nutrient upwelling at hydrographic fronts has been described to promote primary production (Allanson and Parker, 1983; Moon et al., 1998; Froneman et al., 1999). Simulation experiments for the sub-tropics and mid-latitudes suggest that eddy pumping can contribute up to one-third of nutrient fluxes into surface layers (Oschlies and Garçon, 1998) and can increase primary production by roughly $10 \%$, locally even up to $100 \%$ (Spall and Richards, 2000).

Apart from macronutrients, primary production may be limited by the availability of micronutrients like copper, nickel, iron or zink (Morel et al., 1991). Martin (1990) proposes that iron limitation is the dominant factor controlling phytoplankton biomass in the HNLC areas. Indeed, laboratory and field studies (not only in the Southern Ocean) have shown that phytoplankton growth is increased in iron enriched water (e.g. Zettler et al., 1996; Scharek et al., 1997), while iron deficiency limits phytoplankton growth (e.g. Hutchins et al., 1999). A mesoscale iron 
fertilization experiment in the Indian sector of the Southern Ocean (Southern Ocean Iron Release Experiment-SOIREE) produced a significant increase of phytoplankton biomass (Boyd et al., 2000).

In large parts of the surface ocean, aeolian mineral dust is regarded as the main source for iron (e.g. Zhuang et al., 1992). Low aeolian (iron-rich) dust input due to the absence of continents upwind have been discussed to explain the HNLC area of the Southern Ocean (Martin et al., 1990; Kumar et al., 1995).

The observation of enhanced iron concentrations (Löscher et al., 1997) near melting icebergs in the vicinity of the APF led to the hypothesis that an enhanced iron supply may cause the observed increase of phytoplankton biomass in that region (de Baar et al., 1995; Bathmann et al., 1997a). However, as the effect of melting icebergs is purely local and intermittent (Löscher et al., 1997), it cannot cause the regularly observed enhanced biologic activity near the APF. Thus, iron upwelling due to mesoscale frontal dynamics appears to be the only plausible source of regionally enhanced iron concentrations.

Iron upwelling has been reported to promote phytoplankton blooms in various oceanic regions (e.g. Gordon et al., 1998). Even a small transport of iron into the euphotic zone may have a significant effect on carbon export (Coale et al., 1996). Recent studies indicate that $70-80 \%$ of the global carbon export production result from upwelling of dissolved iron (Archer and Johnson, 2000). Variability in primary production in the Atlantic sector of the Southern Ocean has been attributed to variations in iron supply due to fluctuations of oceanic upwelling (Hense et al., 2003).

To investigate which physical or biogeochemical factors may be responsible for higher chlorophyll concentrations in the frontal area, the Biological Model for the Antarctic Plankton Community (BIMAP; Hense et al., 2000, 2003) is coupled to a high resolution application of the ocean circulation model, sCoordinate Primitive Equation Model (SPEM) (Haidvogel et al., 1991). Our main focus here is not the investigation of frontal dynamics, but we use a stateof-the-art primitive equation ocean model in an eddy resolving configuration to provide adequate transport, mixing rates and boundary conditions for the ecosystem model.
The paper starts with a review of recent observations which we use for assessment and validation of model results. Section 3 gives a description of the coupled model. Results from simulations with different nutrient limitation scenarios are presented in Section 4. Simulated chlorophyll concentrations of the different experiments are compared to observations. The paper closes with a discussion and conclusions.

\section{Observations}

Observed summer surface chlorophyll concentrations in the region of the Antarctic Polar Front (APF) reveal a mesoscale meandering structure and a band of high phytoplankton biomass with concentrations up to $1.6 \mu \mathrm{g} \mathrm{Chl} a / 1$ between $50^{\circ} \mathrm{S}$ and $51^{\circ} \mathrm{S}$ (Fig. 1). A comparison with hydrographic observations (Hense, 1997; Strass et al., 2002a) indicates that this band was aligned with the location of the APF, with the maximum concentrations directly south of the northernmost occurrence of the $2{ }^{\circ} \mathrm{C}$-isotherme in $200 \mathrm{~m}$ depth, above the belt of large horizontal temperature gradients.

Similar correlations between hydrography and phytoplankton distribution can be found in meridional transects from different Southern Ocean-JGOFS cruises (Bathmann et al., 1997a,b; Hense, 1997), which show an enhanced phytoplankton biomass with typical surface concentrations between 1.5 and $2.5 \mu \mathrm{g}$ Chl $a / 1$ near the APF while low chlorophyll concentrations with values below $1 \mu \mathrm{g} \mathrm{Chl} a / 1$ occur further north and south (Fig. 2). Differences between these two datasets may be due to different locations of the Polar Front, seasonal variations or interannual variability. They illustrate the natural variability of the system - both datasets represent merely snapshots of a highly diverse dynamic system.

Like the concentrations of phytoplankton, the distributions of nutrients are correlated with mesoscale hydrography (Hartmann et al., 1997) with silicate concentration featuring strong meridional gradients. Typically, silicate at the APF is nearly depleted in summer with values $<1 \mu \mathrm{mol} / 1$ in areas with high phytoplankton concentration, while nitrate concentrations at the APF remain high with values exceeding 20 $\mu \mathrm{mol} / \mathrm{l}$. The depletion of silicate compared to nitrate can be at least partly attributed to heavily silicified 


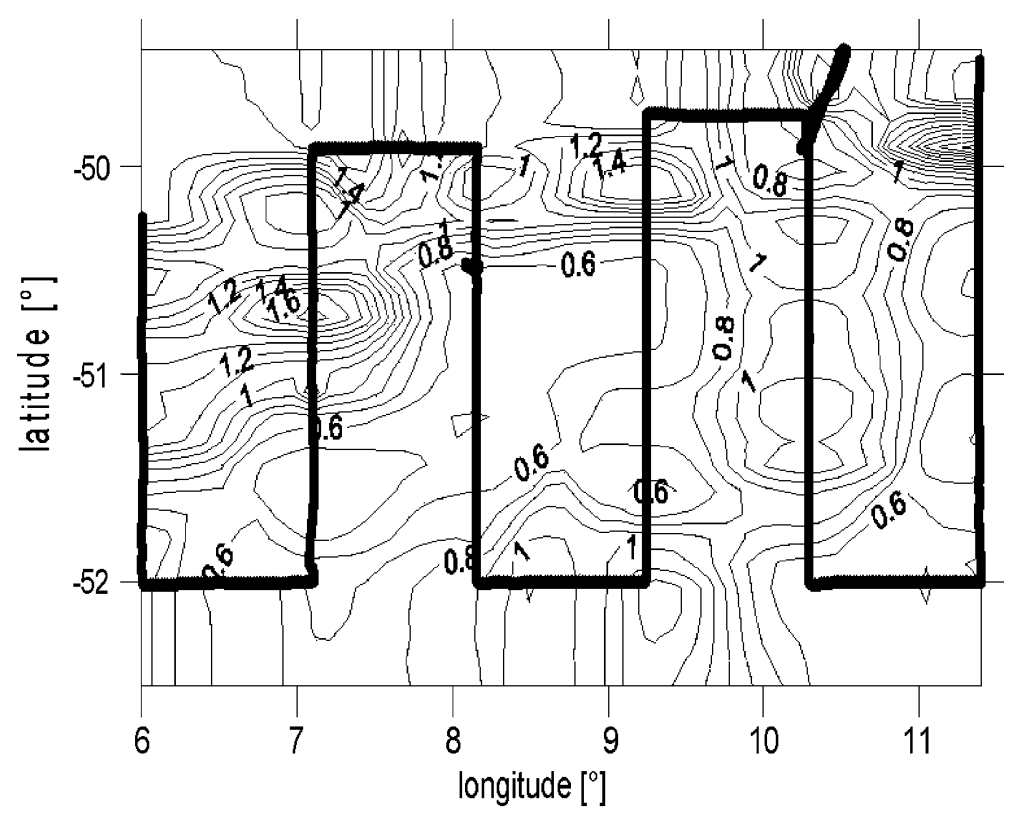

Fig. 1. Horizontal distribution of chlorophyll concentration [ $\mu \mathrm{g} / 1]$ at the surface in December/January 1995/1996, after Hense (1997). Data were collected during Polarstern cruise ANT XIII/2 (Bathmann et al., 1997b). The bold line indicates the cruise track.

diatoms that dominate the phytoplankton community in this area (e.g. Quéguiner et al., 1997). In the southern ACC, typical concentrations are 20-30

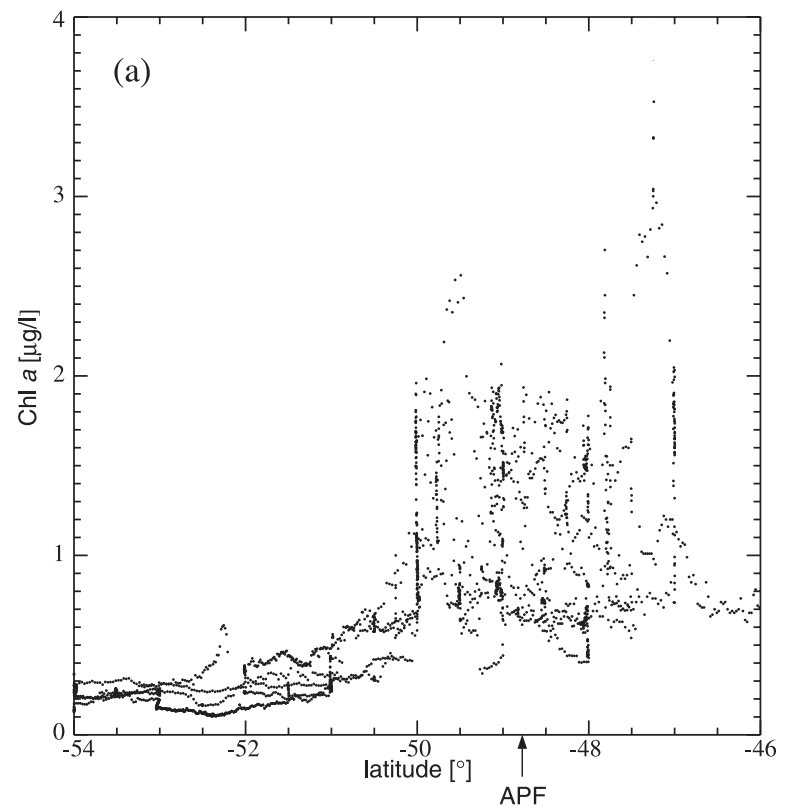

$\mu \mathrm{mol} / \mathrm{l}$ for both nitrate and silicate (Hartmann et al., 1997; Löscher et al., 1997; Veth et al., 1997); silicate concentration further increases to the south.

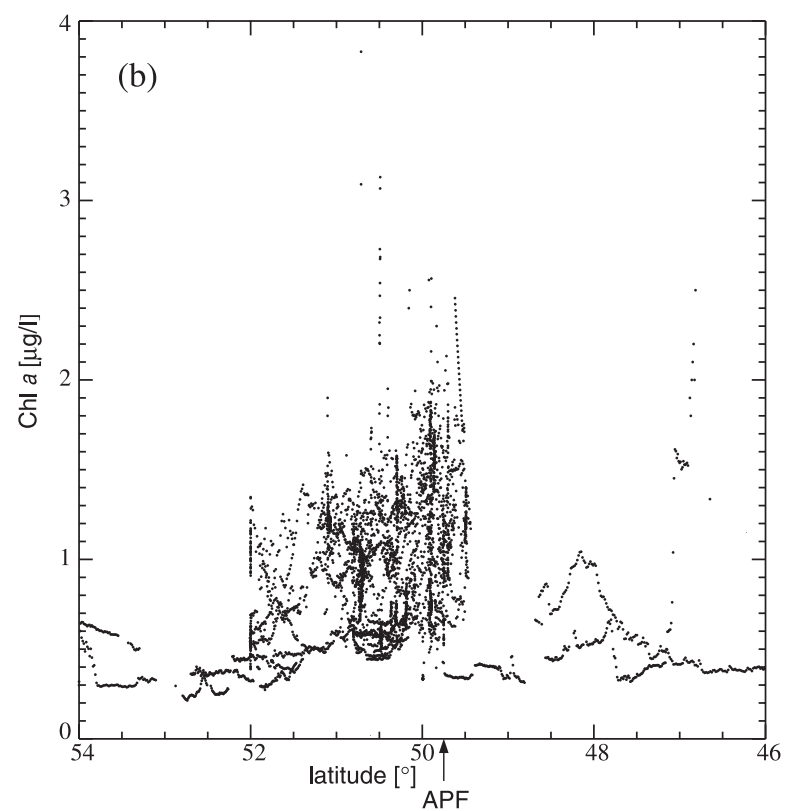

Fig. 2. Meridional transects of surface chlorophyll concentration [ $\mu \mathrm{g} / 1]$ observed (a) in October/November 1992 (after Bathmann et al., 1997a) and (b) in December/January 1995/1996 (after Hense, 1997). 


\section{Model configuration}

\subsection{Model concept}

Following the pioneering nitrogen-phytoplankton-zooplankton-detritus (NPZD) model of Fasham et al. (1990), several marine plankton models with different complexity have been developed. The most complex marine biological model is certainly ERSEM (Baretta et al., 1995; Ebenhöh et al., 1995), with a large number of state variables including also benthic processes. This model is restricted to regional applications like in the North Sea or the Mediterranian Sea, as it requires high computer resources.

For the Southern Ocean, one-dimensional plankton models like SWAMCO (Lancelot et al., 2000) or the KERFIX simulation of Pondaven et al. (1998) have been used to investigate ecosystem dynamics in the context of research cruises or station time series. The physical environment in these models has been reduced to the variability of the mixed layer depth.

On the other hand, coupled ocean-ecosystem models with simple parameterizations of biogeochemical fluxes between four and five compartments have been developed for global (Six and Maier-Reimer, 1996) and regional applications (Oschlies and Garçon, 1999). Typically, horizontal resolution of these models is $1 / 3$ to $3^{\circ}$ thus far too coarse to resolve mesoscale dynamics.

We here present an ecosystem model of intermediate complexity which comprises two biogeochemical cycles and considers possible iron limitations. Wherever possible we use observations to derive parameters for the different fluxes of nutrients and organic matter. While the model is complex enough to cover many aspects of the nonlinear ecosystem dynamics, it is efficient with respect to computing resources which allows coupling to a three-dimensional, eddy-resolving ocean model, and integration for several annual cycles.

\subsection{The ecosystem model}

The Biological Model for the Antarctic Plankton Community (BIMAP) comprises the biogeochemical cycles of silica and nitrogen. Following Fasham et al. (1990), nitrogen is distributed between the compartments phytoplankton $(P)$, zooplankton $(Z)$, the nitro- gen-consisting detritus $\left(D_{\mathrm{N}}\right)$, and the nutrients nitrate $\left(N_{\mathrm{n}}\right)$ and ammonium $\left(N_{\mathrm{a}}\right)$. As the model is supposed to reflect the plankton community in the Antarctic Polar Front, which largely consists of diatoms, a silica cycle is coupled to this by using a fixed $\mathrm{Si} / \mathrm{N}$-uptake ratio for phytoplankton growth; silicate concentration and the silica part of detritus are denoted as $S i$ and $D_{\mathrm{Si}}$, respectively. The model has been adopted from the zero-dimensional simulations of Hense et al. (2000), and has been complemented by a compartment for dissolved iron (Fe; Hense et al., 2003). This biological model has been coupled to a three-dimensional iceocean model and has been used to investigate the mechanisms relevant for regional and interannual variability of primary production and plankton bloom development in the Southern Ocean (Hense et al., 2003).

For the equations, parameters and further information of how the individual values were derived from the different measurements, the reader is referred to Hense et al. $(2000,2003)$. As different Si/Nuptake ratios influence maximum phytoplankton biomass significantly and model experiments indicate that molar Si/N-uptake ratios between 2 and 4 give reasonable results (Hense et al., 2000), we conduct the reference experiment with a molar $\mathrm{Si} / \mathrm{N}$ uptake ratio $r_{\mathrm{Si}}=3$ but carry out two additional experiments with $r_{\mathrm{Si}}=2$ and $r_{\mathrm{Si}}=4$ (Section 4.2). Measurements of half saturation constants of iron are scarce, thus sensitivity experiments with $k_{\mathrm{Fe}}=0.6 \mathrm{nmol} / 1$ and $k_{\mathrm{Fe}}=1.2 \mathrm{nmol} / 1$ (Lancelot et al., 2000) instead of $k_{\mathrm{Fe}}=0.12 \mathrm{nmol} / \mathrm{l}$ (Hense et al., 2003) are carried out (Section 4.2).

\subsection{The ocean model}

The ocean model SPEM (Haidvogel et al., 1991) is based on the primitive equations in hydrostatic approximation and uses a terrain-following vertical coordinate. Horizontal and vertical advection are computed using an explicit second order finite differences scheme (Haidvogel and Beckmann, 1999). Vertical turbulent transport of both physical and biological tracers in our configuration is parameterized using the Pacanowski and Philander (1986) mixing scheme. As in Beckmann et al. (1999), lateral diffusivity is a function of the local Reynolds number. Lateral viscosity is assumed to be a quadratic function 
of the horizontal grid spacing $\Delta$ and varies from 185 to $243 \mathrm{~m}^{2} / \mathrm{s}$.

\subsection{Model domain and grid}

The model domain comprises a periodic channel on a $\beta$-plane with closed boundaries in the north and south forming a region of 1709 by $858 \mathrm{~km}^{2}$ of size centered at $50^{\circ} \mathrm{S}$ (Fig. 3), which is the approximate location of the Antarctic Polar Front in the Atlantic sector of the Southern Ocean. The model grid is isotropic and has a horizontal resolution of $1 / 12^{\circ}$ in the zonal and $1 / 12^{\circ} \cos \phi$ in the meridional direction, which leads to a grid spacing of typically $6 \mathrm{~km}$. Thus, the model runs in an eddy-resolving configuration, which allows for the development of dynamic instabilities. The vertical grid is terrain-following with resolution increasing near the surface. For optimal representation of near-surface dynamics, 9 of the 24 layers are situated in the uppermost $80 \mathrm{~m}$.

Bottom topography is idealized with no variability in the zonal direction and represents the large-scale bathymetry of the Atlantic sector of the Southern Ocean as derived from the dataset of Smith and Sandwell (1997). From a maximum water depth of $4000 \mathrm{~m}$ in the north, the seafloor rises to a minimum depth of $2500 \mathrm{~m}$ in the south (Fig. 4), representing the Atlantic Indian Ridge.

\subsection{Initialization, boundary conditions and time- stepping}

The ocean model as well as the nutrients silicate and nitrate are initialized using data from the WOCE Hydrographic Program Office dataset (1998), which were zonally averaged over the area of the model domain. The nutrient distribution is characterized by strong meridional gradients: Minimum surface concentrations of nitrate and silicate are 23 and $4 \mu \mathrm{mol} / \mathrm{l}$, respectively, and are found in the north. To the south, surface nutrient concentrations increase to 27.7 and $35.7 \mu \mathrm{mol} / 1$ for nitrate and silicate, respectively.

Due to the lack of gridded data, iron concentration is initialized using the linear profile

$$
\begin{aligned}
\mathrm{Fe}^{t=0}(z)= & 3 \times 10^{-3} \mathrm{mmol} \mathrm{m}^{-3} \\
& +1.425 \times 10^{-6} \mathrm{mmol} \mathrm{m}^{-4}|z|
\end{aligned}
$$

which fits to iron concentrations at the surface and at the bottom derived from measurements in the APF region (Löscher et al., 1997). As no horizontal gradients are prescribed initially, any horizontal inhomogeneity in the iron distribution developing during the integration can be attributed to the combined effects of frontal and ecosystem dynamics.

At the northern and southern boundary of the model domain, a restoring to the initial salinity, temperature, and nitrate, silicate and iron concentrations is applied below $1600 \mathrm{~m}$ depth. In addition, a restoring zone for salinity and temperature along the periodic boundary ensures the persistence of the front even for an integration over several years. An eastward transport of $130 \mathrm{~Sv}$ through the model domain is prescribed.

Surface boundary conditions are derived from a diagnostic surface energy balance which is based on the treatment of open water in the thermodynamic sea ice model of Parkinson and Washington (1979) as implemented in the coupled sea ice-ocean model of Timmermann et al. (2002). For the solar radiation the

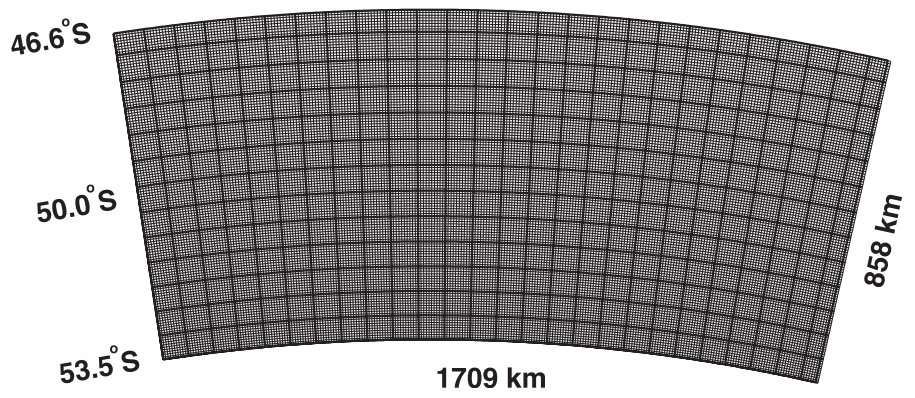

Fig. 3. Horizontal model grid. 


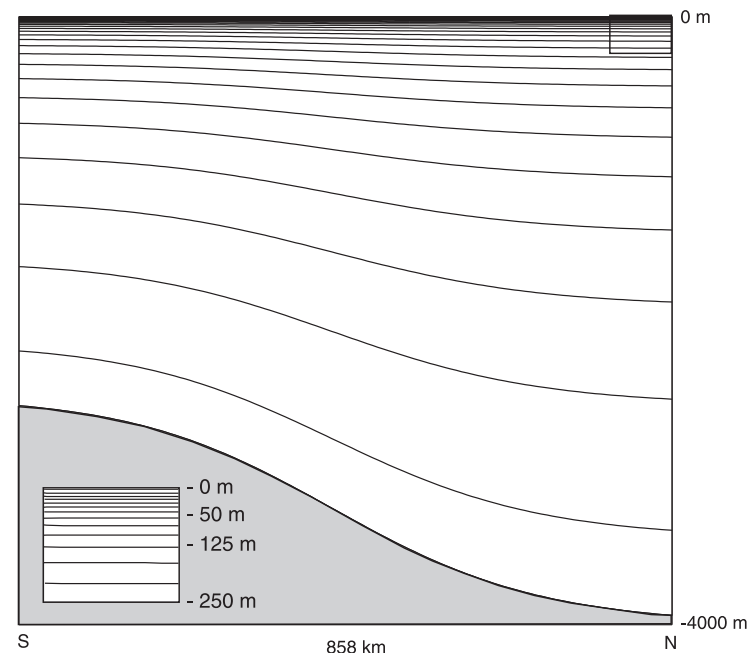

Fig. 4. Vertical discretization of the water column.

daily and annual cycles as well as the latitude and mean cloud cover, using the standard astronomical formulae of Zillmann (1972) and Laevastu (1960), are considered. Total cloud cover was chosen to be $70 \%$ for the whole model domain, in agreement with the reanalysis of the European Center for Medium-Range Weather Forecasts (ECMWF).

To avoid artificial up- and downwelling at the closed northern and southern boundaries due to Ekman transport, atmospheric surface stress is neglected. The wind-induced vertical shear required by the Pacanowski and Philander (1986) mixing scheme is prescribed as an empirical vertical profile (horizontally uniform) that was derived from model experiments which included surface stress by ECMWF wind forcing.

Forcing data were derived from the ECMWF reanalysis, including 6-hourly data of $10 \mathrm{~m}$ wind, and 2 $\mathrm{m}$ air and dew point temperatures. The model is integrated for 33 months. A 3-min time step is applied.

For the first 270 days, the biological variables are restored to their initial values while the ocean is free to develop dynamic instabilities. From there, we start the experiments with winter concentrations and a fully developed meandering current. Results presented below are from the period between October of the second year and September of the third year of integration.
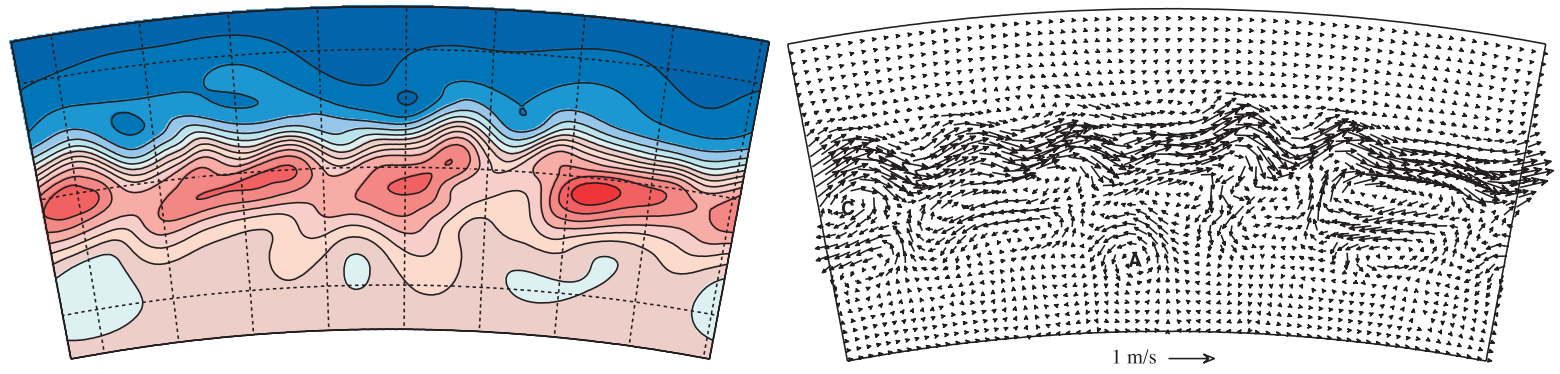

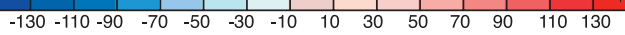
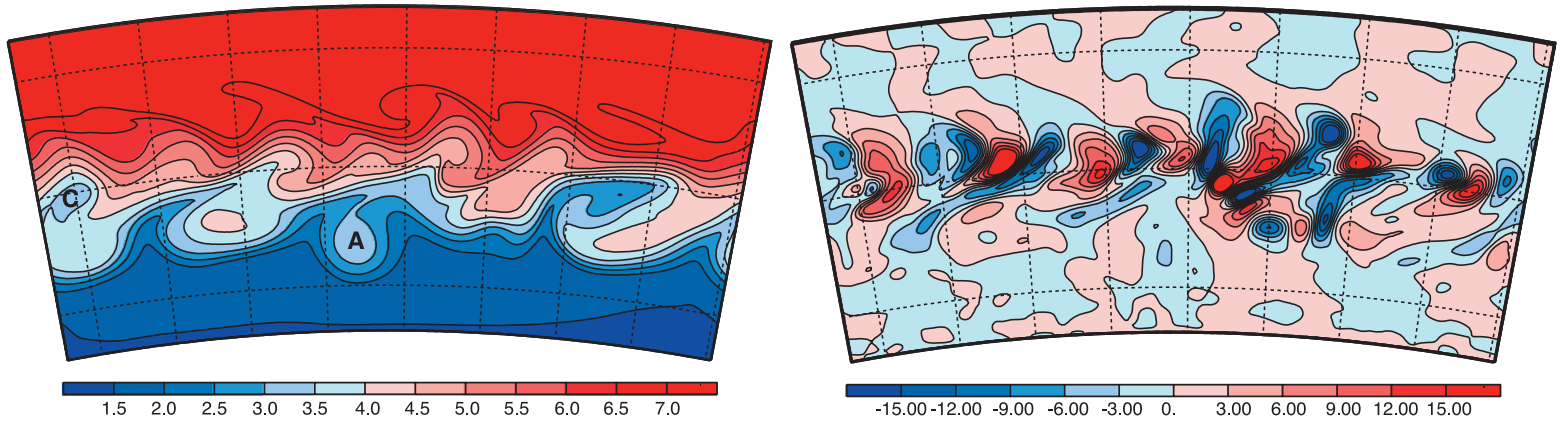

Fig. 5. Snapshots of vertically integrated transport $[\mathrm{Sv}]$ (top left), surface horizontal velocity $[\mathrm{m} / \mathrm{s}]$ (top right), surface temperature $\left[{ }^{\circ} \mathrm{C}\right]($ bottom left) and vertical velocity [m/day] in $200 \mathrm{~m}$ depth (bottom right) after 350 days of integration. An anticyclonic eddy is marked as A, a cyclonic eddy as $\mathrm{C}$. 


\section{Model results}

\subsection{Hydrography and frontal dynamics}

After 60 days of integration, the typical structure of a meandering front has evolved. From that point onwards, the level of mesoscale variability is retained over the full simulation. Vertically integrated transport (Fig. 5, top left) and surface velocities (Fig. 5, top right) after 350 days of integration feature a pronounced frontal jet with typical surface velocities of $0.5 \mathrm{~m} / \mathrm{s}$, a weak recirculation south of the jet and a realistic meandering structure: The width of the frontal jet ranges between 120 and 140 $\mathrm{km}$, in agreement with observations of Lutjeharms and Valentine (1984). Due to the high eastward velocities within the frontal zone, the meanders propagate eastward, against the direction of freely propagating Rossby waves (retrograde propagation). Their typical wavelength of $160-180 \mathrm{~km}$ is close to the $175 \mathrm{~km}$ wavelength observed by Cowles et al. (2000).

Occasionally, eddies are shed from the baroclinically unstable frontal current. Cyclones are formed south of the frontal jet, whereas anticyclones are shed north of it (southern hemisphere). However, as the frontal jet in our simulation is situated north of the maximum topographic slope, eddy generation is more efficient on the southern (steeper) side where eddies leave the frontal jet and propagate prograde (i.e. in the direction of freely propagating waves; here: to the west) at about $20 \mathrm{~cm} / \mathrm{s}$.

Cyclonic and anticyclonic eddies (marked by " $\mathrm{C}$ " and " $\mathrm{A}$ " in Fig. 5) can be distinguished in the surface temperature (Fig. 5, bottom left) as cold and warm core anomalies, respectively. These eddies have a diameter of roughly $80 \mathrm{~km}$ which corresponds to the spatial decorrelation scale of $85 \mathrm{~km}$ derived from Geosat altimeter data for the ACC (Gille and Kelly, 1996). Observed diameters of eddies or rings in the ACC generally cover a wide range from 60 to $250 \mathrm{~km}$ (Bryden, 1983; Nowlin and Klinck, 1986; Gouretski and Danilov, 1994).

The meandering current and eddy formation lead to mesoscale up- and downwelling (Fig. 5, bottom right). Applying the principle of potential vorticity conservation, we can see that the gain of relative vorticity, i.e. the transition from anticyclonic to cyclonic flow is associated with local downwelling, while flow in transition from cyclonic to anticyclonic relative vorticity coincides with mesoscale upwelling regions (Onken, 1992). Thus, downwelling occurs on the upstream side (for an eastward current, i.e. the western side) of each cyclonic meander ridge, while upwelling takes place downstream (here: east) of it. These structures in the meandering current have been also observed in the region of the Polar Front by Strass et al. (2002a). Typical vertical velocities in these up- and downwelling cells range from 5 to $20 \mathrm{~m} /$ day and thus are considerably larger than the vertical velocities inside isolated eddies which do not exceed $3 \mathrm{~m} /$ day.

As proposed from observations (e.g. Strass et al., 2002a), mesoscale upwelling near the meandering front affects the mixing depth near the surface: While the zonal mean mixed layer depth in the northern and southern ACC ranges from 60 to 155 $\mathrm{m}$ in the annual cycle, zonal mean mixed layer depth near the APF is only $35 \mathrm{~m}$ in summer and $120 \mathrm{~m}$ in winter (Fig. 6). Local mixed layer depth near the APF can be as shallow as $20 \mathrm{~m}$.

The time- and spatial mean cross front overturning circulation (Fig. 7) features two pronounced overturning cells producing an intense upwelling region which is situated roughly in the center of the model domain. Two weaker counterrotating cells further north, i.e. near the base of the prescribed ridge, produce a secondary upwelling region. Downwelling outside the frontal area but also in the convergence between the two upwelling cells closes the mass balance. At this point, we are not able to validate this

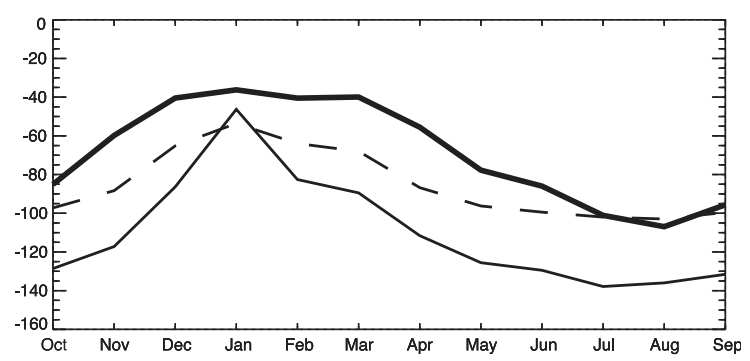

Fig. 6. Zonal mean of the seasonal cycle of the mixed layer depth $[\mathrm{m}]$ in the vicinity of the front (bold), in the northern ACC (solid) and southern ACC (dashed). 


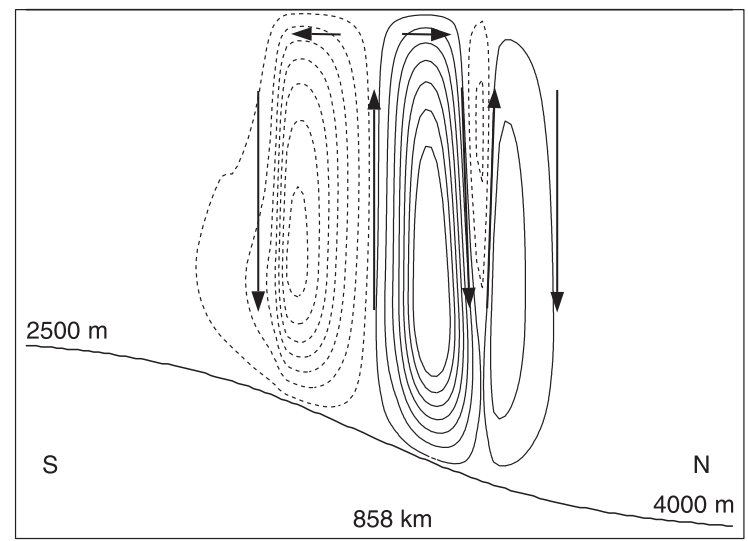

Fig. 7. Yearly mean of the zonally integrated meridional overturning circulation. Contours range from -3.25 to $3.25 \mathrm{~Sv}$; contour interval is $0.5 \mathrm{~Sv}$. Dashed lines indicate negative values. The same structure is visible in monthly means.

structure. However, we will demonstrate that it produces a phytoplankton distribution in close resemblance to observations.

\subsection{Ecosystem dynamics (1): no iron limitation}

Following the studies of Hense et al. (2000), the first experiment was carried out with the compartments phytoplankton, zooplankton, nitrate, ammonium, silicate and the two detritus pools. Iron limitation in this experiment was omitted.

A snapshot of simulated phytoplankton biomass in summer shows high chlorophyll concentrations in the frontal system and south of it (Fig. 8, left), reaching values of up to $3 \mu \mathrm{g}$ Chl $a / 1$ near the southern boundary. The mesoscale phytoplankton distribution reflects the meanders and eddies discussed in the previous section. A cyclonic eddy (C) at the western boundary can be distinguished by slightly higher chlorophyll concentrations - corresponding to an increased silicate concentration in this cell-whereas in the anticyclonic eddy (A) further south chlorophyll concentrations are decreased. Nevertheless, locally enhanced phytoplankton biomass in the region of the front cannot be found; instead a strong north-south gradient of phytoplankton biomass is established and present throughout the year.

Following the distribution of phytoplankton biomass, zooplankton concentrations are increased in the southern part (Fig. 8, right), reaching values up to $9 \mu \mathrm{g}$ $\mathrm{C} / \mathrm{l}$, while in the northern part zooplankton concentration does not exceed $2 \mu \mathrm{g} \mathrm{C} / 1$. Again the cyclonic eddy can be distinguished by slightly enhanced zooplankton concentrations, whereas in the anticyclonic cell zooplankton concentrations are decreased.

In the zonal mean, the meridional gradient of silicate which limits phytoplankton growth in the north, is well pronounced (Fig. 9). Phyto- and zooplankton biomass as well as the total biogenic silica increase in the southern part of the model domain. Effects of mesoscale dynamics at the APF are not visible.

Similar to the studies of Hense et al. (2000), model experiments with different values for the $\mathrm{Si} / \mathrm{N}$ uptake ratio $r_{\mathrm{Si}}$ feature variations of the maximum phyto- and zooplankton biomass with increasing concentrations for lower values of $r_{\mathrm{Si}}$, but no change in the general horizontal distribution with high concentrations of phytoplankton in the southern, silicate-rich water mass and low concentrations of phytoplankton in the northern, silicate-poor water mass.

We conclude that the "traditional" model configuration which disregards possible iron limitation is not able to reproduce general features of the large-scale plankton distribution in the Atlantic sector of the Southern Ocean, namely the occurrence of the HNLC area in the southern ACC. As the model gives a reasonable representation of the local frontal dynamics, this does imply that frontal dynamics alone cannot be responsible for the observed phytoplankton maximum in the vicinity of the Antarctic Polar Front.

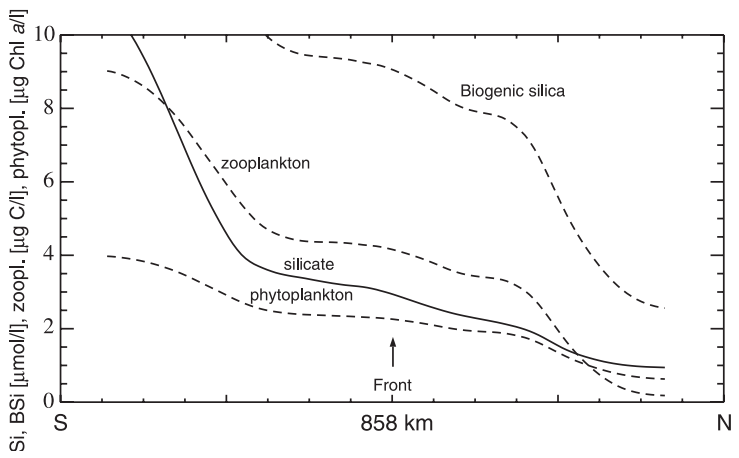

Fig. 9. Zonal means of surface concentrations of dissolved silicate $[\mu \mathrm{mol} / 1]$, biogenic silica $[\mu \mathrm{mol} / 1]$, phyto- $[\mu \mathrm{g} \mathrm{Chl} a / 1]$ and zooplankton $[\mu \mathrm{g} \mathrm{C} / 1]$ at day 350 . 

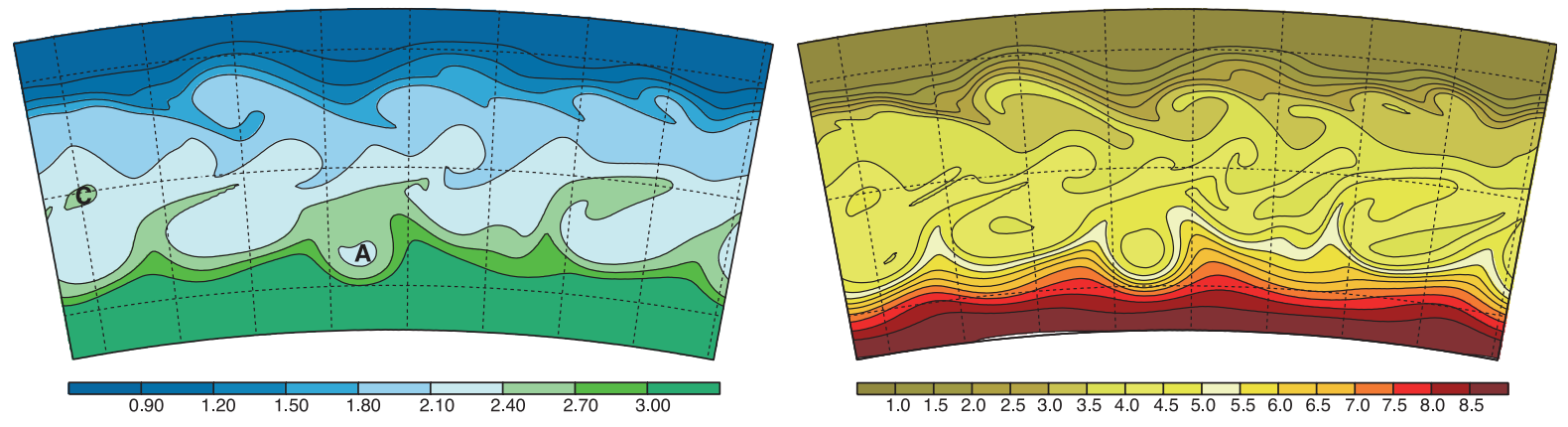

Fig. 8. Snapshots of simulated summer surface concentration of phytoplankton [ $\mu \mathrm{g}$ Chl $a / 1]$ (left) and zooplankton [ $\mu \mathrm{g} \mathrm{C} / 1]$ (right) at day 350 in an experiment neglecting iron limitation.

\subsection{Ecosystem dynamics (2): iron limitation, the reference simulation}

\subsubsection{Seasonal cycle and horizontal distribution}

Introducing an additional iron compartment (Hense et al., 2003) leads to pronounced changes in the simulated ecosystem. Similar to the experiment described in the previous section, phytoplankton growth starts in September/October, following the increasing solar radiation. Distributions of iron and silicate at this time in spring show strong meridional gradients with an iron maximum in the north and a silicate maximum in the south (Fig. 10) while nitrate is more homogeneously distributed with concentrations between 20 and $21 \mu \mathrm{mol} / \mathrm{l}$.

High primary production rates with values of $45 \mathrm{mg}$ $\mathrm{C} \mathrm{m}^{-3}$ day $^{-1}$ occur in the vicinity of the Polar Front, which are in agreement with calculations from this area of maximum $56 \mathrm{~m} \mathrm{C} \mathrm{m}^{-3}$ day $^{-1}$ (Strass et al., 2002b) and lead to maximum concentrations of phytoplankton in November/December. The zooplankton maximum occurs roughly 20 days later. Unlike the results in the "no iron limitation"-experiment, maximum concentrations of phyto- and zooplankton occur in the vicinity of the Polar Front (Fig. 11, top panels) which agrees with observations.

Grazing pressure on phytoplankton is rather small and never exceeds primary production. Maximum simulated grazing rates are $3 \%$ of the primary production and agree well with results from laboratory experiments of Dubischar and Bathmann (1997), which yielded grazing rates of $0.3-3.7 \%$ of primary production.

Again, the large-scale distribution is modulated by mesoscale structures which are visible in all biological tracers. The cyclonic eddy at the western boundary can be distinguished by a higher phyto- and zooplankton biomass. This eddy was generated from a meander directly south of the front which carried higher plankton concentrations and is now an isolated maximum.
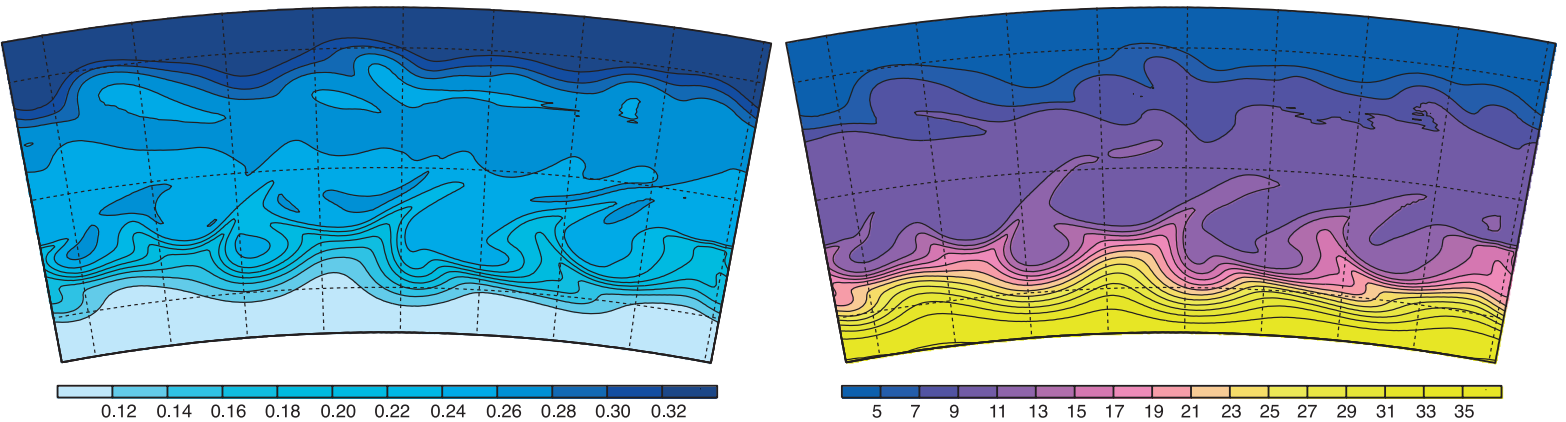

Fig. 10. Snapshots of simulated spring surface concentration of dissolved iron [nmol/1] (left) and dissolved silicate [ $\mu$ mol/1] (right) at day 280 in the standard iron experiment. 

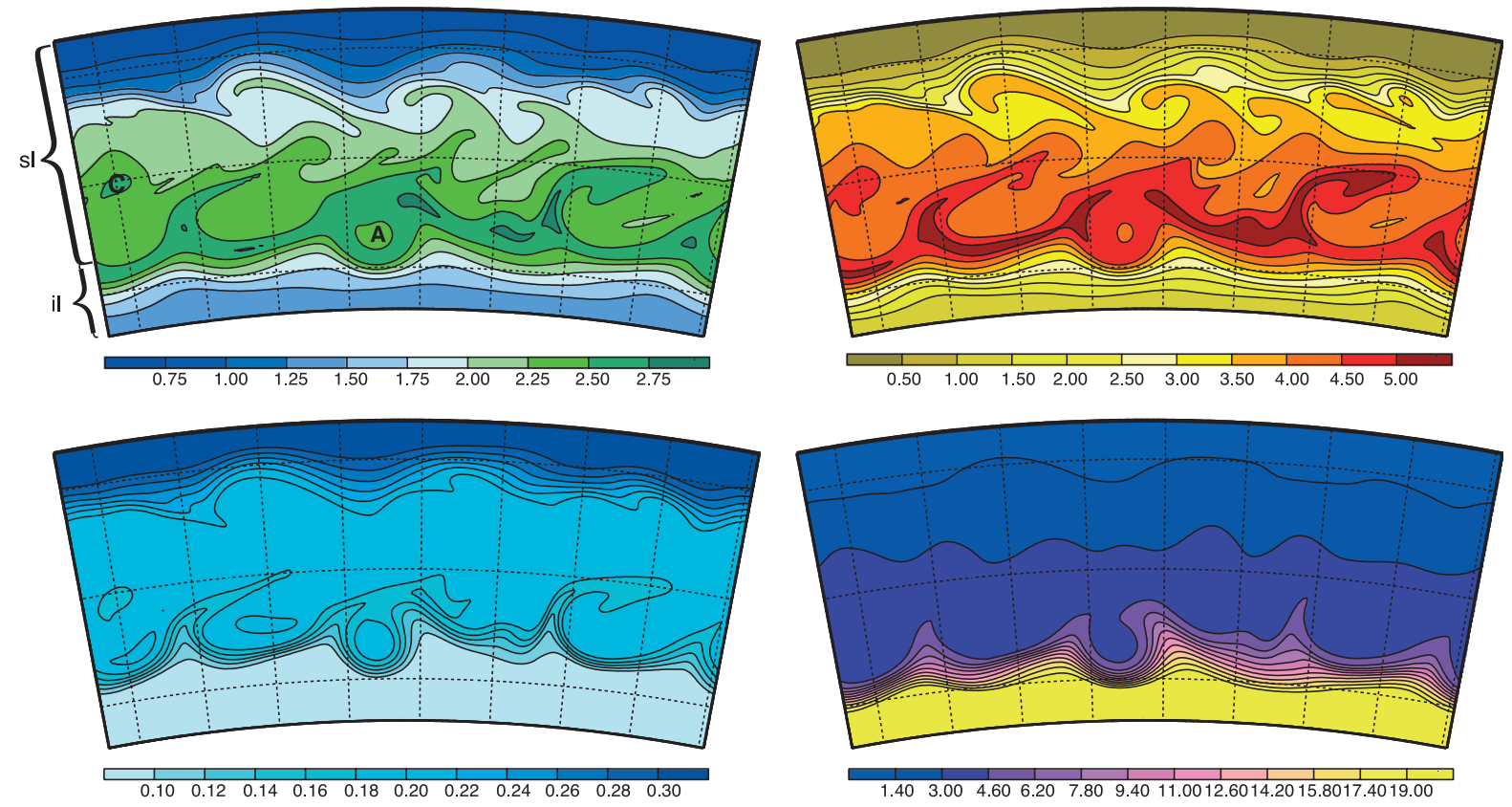

Fig. 11. Snapshots of simulated summer surface concentration of phytoplankton [ $\mu \mathrm{g}$ Chl $a / 1]$ (top left), zooplankton [ $\mu \mathrm{g}$ C/l] (top right), dissolved iron [nmol/1] (bottom left) and dissolved silicate [ $\mu \mathrm{mol} / 1]$ (bottom right) at day 350 in the standard iron experiment. An anticyclonic eddy is marked as A, a cyclonic eddy as C. The symbols "sl" and "il" indicate the zones of silicate and iron limitation, respectively.

In the southern anticyclonic eddy, on the other hand, plankton biomass is significantly lower and iron concentration higher than in the surrounding water mass. This eddy originates from a meander north of the front where silicate limits phytoplankton growth. Again, the properties of that water mass are retained in the eddy.

In the meandering current, low phytoplankton concentrations coincide with upwelling spots, whereas maximum phytoplankton concentrations occur in downwelling areas (Fig. 12).We argue that "newly" upwelled water, rich in nutrients but poor in phytoplankton, is advected horizontally near the surface and phytoplankton grows until water is downwelled on the western side of a cyclonic meander ridge. This process leads to a typical mesoscale phytoplankton distribution and was also postulated from observations in the Atlantic region of the Antarctic Polar Front (Strass et al., 2002a). In the downwelling areas, enhanced phytoplankton concentrations with values about 2.6 $\mu \mathrm{g} \mathrm{Chl} a / 1$ and a depth-integrated phytoplankton stock of $275 \mathrm{mg} \mathrm{m}^{-2}$ agree with observed chlorophyll concentrations between 2 and $4 \mu \mathrm{g}$ Chl $a / 1$ and a depth-integrated biomass of $177-277 \mathrm{mg} \mathrm{m}^{-2}$ (Tréguer and Jacques, 1992; Bathmann et al., 1997a) in the region of the Polar Front.

Similar to the mesoscale distribution of phytoplankton in the meander current, also zooplankton concentration is increased in the downwelling regions with concentrations reaching $5 \mu \mathrm{g} \mathrm{C} / \mathrm{l}$. Compared to observations, which are in the range between 4 and 7 $\mu \mathrm{g}$ C/1 (Fransz and Gonzalez, 1997; converted from

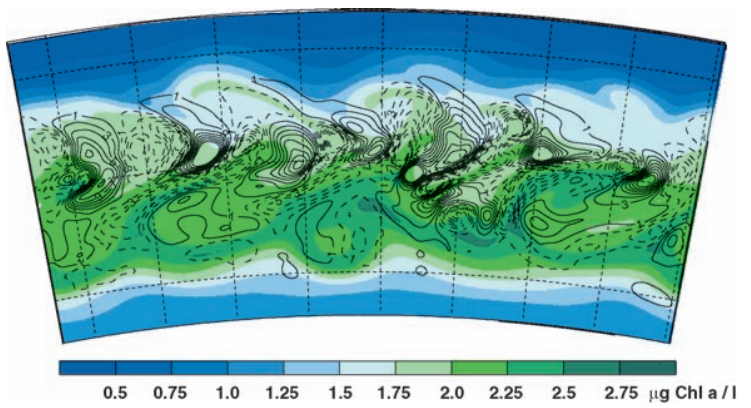

Fig. 12. Same snapshot of simulated summer surface phytoplankton concentration as in Fig. 11 but overlaid are the contour lines of the vertical velocity from Fig. 5 . 


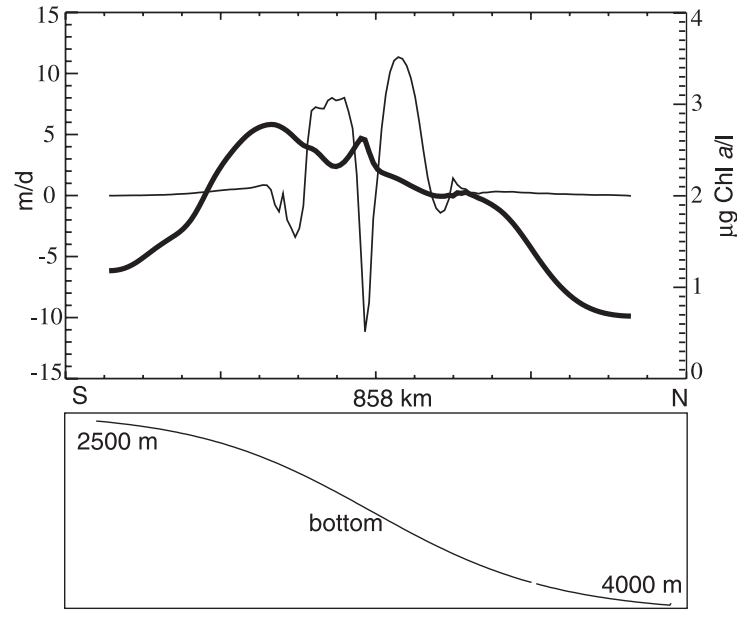

Fig. 13. Meridional transect of the zonal mean vertical velocity in $200 \mathrm{~m}$ depth (thin line) and simulated surface phytoplankton concentration (bold line) in November.

dry mass, see Hense et al., 2000) model results appear thoroughly reasonable.

The same is true for the horizontal distribution of biogenic silica which follows the maxima and minima of plankton concentrations. Maximum simulated values of up to $10 \mu \mathrm{mol} / \mathrm{l}$ occur in the vicinity of the front and are in agreement with observed BSi concentrations of up to $11.7 \mu \mathrm{mol} / \mathrm{l}$ (Quéguiner et al., 1997).

Due to the uptake by phytoplankton, silicate and iron concentrations decrease during the summer (Fig. 11, bottom panels). Silicate increasingly limits phytoplankton growth in the north. Observed horizontal silicate gradients in the region of the Polar Front can be in the order of $7.22 \mu \mathrm{mol} / \mathrm{l} / \mathrm{km}$ (Dafner and Mordasova, 1994), whereas nitrate is more homogenously distributed and shows only little seasonality (Löscher et al., 1997; Dafner and Mordasova, 1994). Model results are consistent with these observations: While surface silicate concentrations vary from $<1$ to $15 \mu \mathrm{mol} / 1$ in the annual cycle, nitrate concentrations are always larger than $20 \mu \mathrm{mol} / \mathrm{l}$.

Due to the silicate limitation of phytoplankton growth, iron concentration remains high in the northern part of the model domain. In the southern ACC, however, where silicate supply is sufficient, phytoplankton growth is increasingly limited by iron depletion. Typical simulated surface iron concentrations in this region are as low as $0.1 \mathrm{nmol} / 1$ and therefore at the lower edge of observed iron concentrations. Until the end of January, silicate is nearly depleted in areas with high iron concentration but does not drop below $20 \mu \mathrm{mol} / 1$ in the southern ACC. Due to the decreasing solar radiation and increasing mixed layer depth, phytoplankton growth decreases, however, even in winter a slightly enhanced phytoplankton biomass is found in the frontal region with concentrations of up to $0.3 \mu \mathrm{g} \mathrm{Chl} a / 1$ — compared to $0.1 \mu \mathrm{g} \mathrm{Chl} a / 1$ further north and south.

\subsubsection{Meridional structure of phytoplankton distri- bution}

A meridional section of simulated phytoplankton concentrations and zonally integrated vertical velocity in $200 \mathrm{~m}$ depth reveals the two upwelling spots separated by a pronounced downwelling cell (Fig. 13) which have been already visible in the meridional overturning circulation. Again, as in the mesoscale distribution, the downwelling area coincides with the phytoplankton maximum while the two upwelling spots bare themselves as low chlorophyll and high nutrient areas. Similar to the processes at the meander ridges, nutrient rich (i.e. iron rich), chlorophyll poor water is upwelled. Water and properties are spread horizontally near the surface and phytoplankton grows until the water and the phytoplankton community encounter a downwelling region and are shifted downwards, out of the euphotic zone (Fig. 14), where phytoplankton growth has to stop. Thus minimum (maximum) phytoplankton concentrations are found in upwelling (downwelling) areas. Outside the frontal system, newly upwelled water is mixed with water, which is poor in either silicate or iron; thus phytoplankton blooms cannot develop.

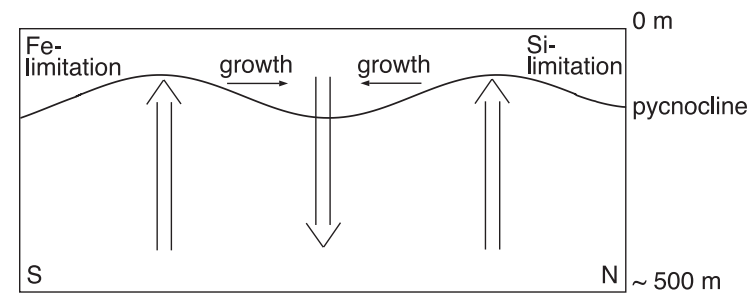

Fig. 14. Schematic representation of up- and downwelling effects on phytoplankton growth. 


\subsection{Sensitivity experiments}

\subsubsection{Sensitivity studies on different $k_{F e}$}

To test the sensitivity on different half saturation constants for iron, we performed two experiments with iron half saturation constants $k_{\mathrm{Fe}}=0.6 \mathrm{nmol} /$ 1 and $k_{\mathrm{Fe}}=1.2 \mathrm{nmol} / 1$ (Lancelot et al., 2000), respectively.

Both experiments feature a regionally increased plankton biomass near the APF (Fig. 16, magenta and yellow line). Silicate limitation occurs in most of the model domain; the location of the boundary between silicate and iron limitation, however, does not differ much from the reference experiment. Striking are the differences in the concentration of phytoplankton. In both experiments, phytoplankton concentrations are overall lower compared to the reference experiment (Fig. 16, red line). Whereas phytoplankton concentrations in summer are maximum $1.8 \mu \mathrm{g}$ Chl $a / 1$ in the simulation with $k_{\mathrm{Fe}}=0.6$ nmol/1, phytoplankton concentration does not exceed $0.18 \mu \mathrm{g} \mathrm{Chl} a / 1$ in the experiment with $k_{\mathrm{Fe}}=1.2 \mathrm{nmol} /$ 1 (Fig. 16, magenta and yellow line in the right panel). Apparently, experiments with a half saturation constant of $k_{\mathrm{Fe}}=1.2 \mathrm{nmol} / 1$ strongly underestimate primary production. Due to lower primary production, zooplankton biomass is strongly decreased with maximum concentrations of $0.4 \mu \mathrm{g} \mathrm{C} / 1$ in the simulation with $k_{\mathrm{Fe}}=0.6 \mathrm{nmol} / 1$ and $0.02 \mu \mathrm{g} \mathrm{C} / 1$ in the experiment with $k_{\mathrm{Fe}}=1.2 \mathrm{nmol} / 1$.

\subsubsection{Sensitivity studies on different $r_{s i}$}

Motivated by observations indicating a varying degree of silicification in diatom species in the Southern Ocean (Shiomoto and Ishii, 1995; Quéguiner et al., 1997; Hense et al., 1998) and the results of zerodimensional model experiments with different $\mathrm{Si} / \mathrm{N}$ uptake ratios (Hense et al., 2000), additional experiments with different $r_{\mathrm{Si}}$ were performed.

Like the reference experiment, the simulations feature a phytoplankton distribution with a maximum in the vicinity of the APF. The experiments differ, however, in location and width of the band with high phytoplankton concentrations:

In the experiment with $r_{\mathrm{Si}}=2$ (Fig. 16, blue line; Fig. 15, left panel) the band of high phytoplankton concentrations is significantly wider than in the experiments with higher $\mathrm{Si} / \mathrm{N}$ uptake ratios and centered directly at the simulated front. Typical maximum phytoplankton concentrations in summer are between 2.5 and $2.75 \mu \mathrm{g} \mathrm{Chl} a / 1$ and coincide with the results of the standard iron experiment. Iron limitation dominates primary production in the greatest part of the model domain. Due to the lower incorporation of silica per nitrogen unit, less silicate is taken up and phytoplankton grows until iron limitation occurs. The anticyclonic eddy in the south is now characterized by higher phytoplankton compared to the surrounding water mass and therefore differs from all the other experiments where this eddy always features decreased phytoplankton concentrations (Fig. 15, left panel). The difference is that in this simulation primary production within the eddy is not limited by silicate depletion, due to higher silicate concentrations in the meander from which the eddy originates.

Seawater and culture experiments indicate that the $\mathrm{Si} / \mathrm{N}$ uptake ratio is influenced by iron concentration (Takeda, 1998; Hutchins and Bruland, 1998); therefore an iron-dependent diagnostic $\mathrm{Si} / \mathrm{N}$ uptake ratio has been introduced. Using data from experiments
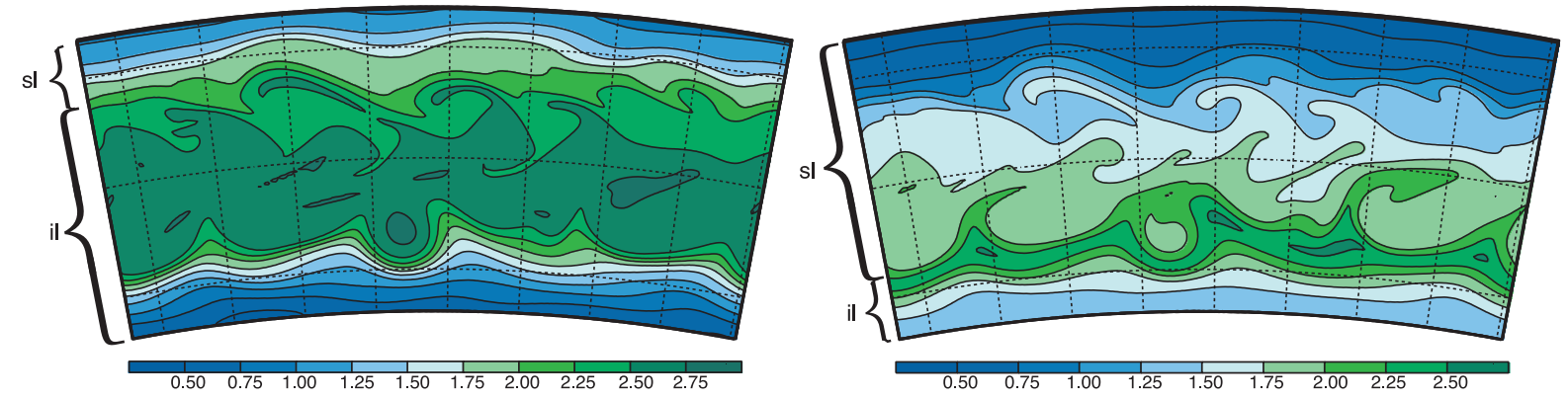

Fig. 15. Snapshots of simulated summer surface concentration (day 350) of phytoplankton [ $\mu \mathrm{g}$ Chl $a / 1]$ in the experiment of $r_{\mathrm{Si}}=2$ (left) and $r_{\mathrm{Si}}=4$ (right). The symbols "sl" and "il" indicate the zones of silicate and iron limitation, respectively. 
with an Antarctic diatom (Takeda, 1998) we deduced the linear relationship

$r_{\mathrm{Si}}=-1.3 \times 10^{3} \frac{\mathrm{m}^{3}}{\mathrm{mmol}} \mathrm{Fe}+2.51$

for a series of sensitivity studies. However, it turned out that the range of the diagnostically derived $\mathrm{Si} / \mathrm{N}$ uptake ratio is rather small with values between 2.2 in the north and 2.4 in the southern ACC. Consequently, model results from these experiments show only minor differences from the simulation with $r_{\mathrm{Si}}=2$. We conclude that in a natural environment variations of the Si/N-uptake ratio due to differences in iron concentrations are too small to have a significant effect on the distribution of phytoplankton biomass.

Compared to the reference run and the experiment with an $\mathrm{Si} / \mathrm{N}$ uptake ratio $r_{\mathrm{Si}}=2$, in the experiment with $r_{\mathrm{Si}}=4$ the band of high phytoplankton concentrations is much narrower and located further south. Phytoplankton concentrations are significantly lower

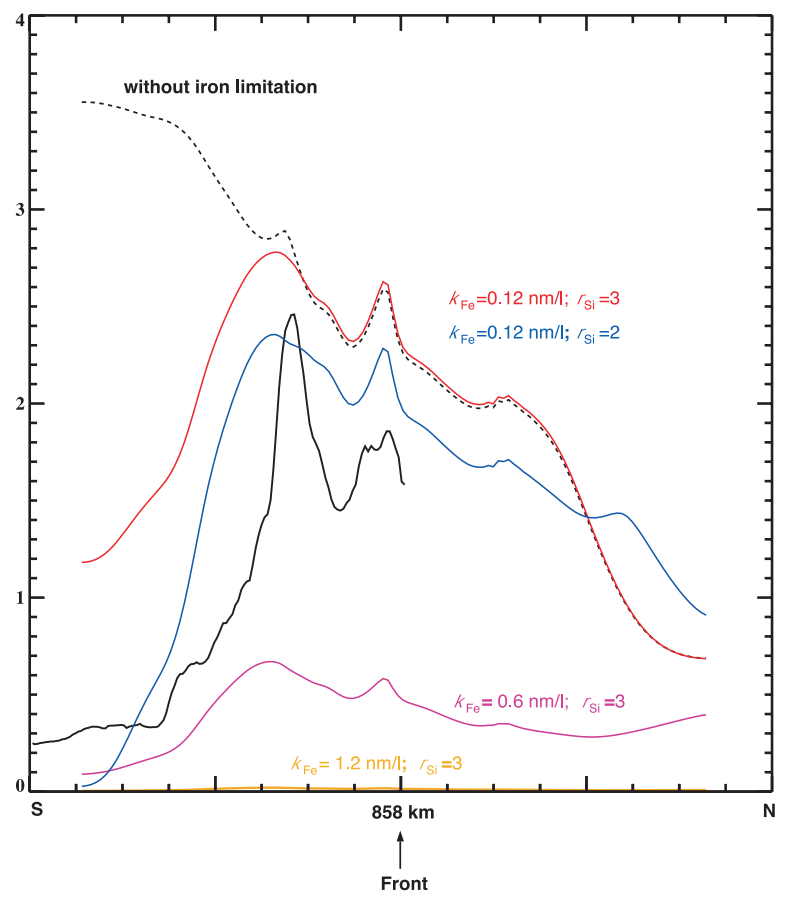

with values between 2 and $2.25 \mu \mathrm{g}$ Chl $a / 1$ (Fig. 15, right panel). Due to strong silicate limitation to the north, phytoplankton concentration decreases stronger compared to the reference run. Again, the effect on zooplankton biomass is stronger than on phytoplankton biomass. Zooplankton concentrations are between 0.4 and $4 \mu \mathrm{g} \mathrm{C} / 1$ south of the front and in the meander current. Phytoplankton growth and zooplankton grazing are kept in a dynamic balance, which compensates increased (decreased) primary production by increased (decreased) zooplankton grazing.

\subsection{Validation}

Comparing the experiments with observations of 1992 and 1995 (Fig. 16, black lines), it is striking that the horizontal pattern with enhanced chlorophyll concentration in the frontal region is only reflected in the experiments including iron limitation (Fig. 16, coloured lines). The "no iron limitation" experiment (Fig. 16, dotted line) can be distinguished by a

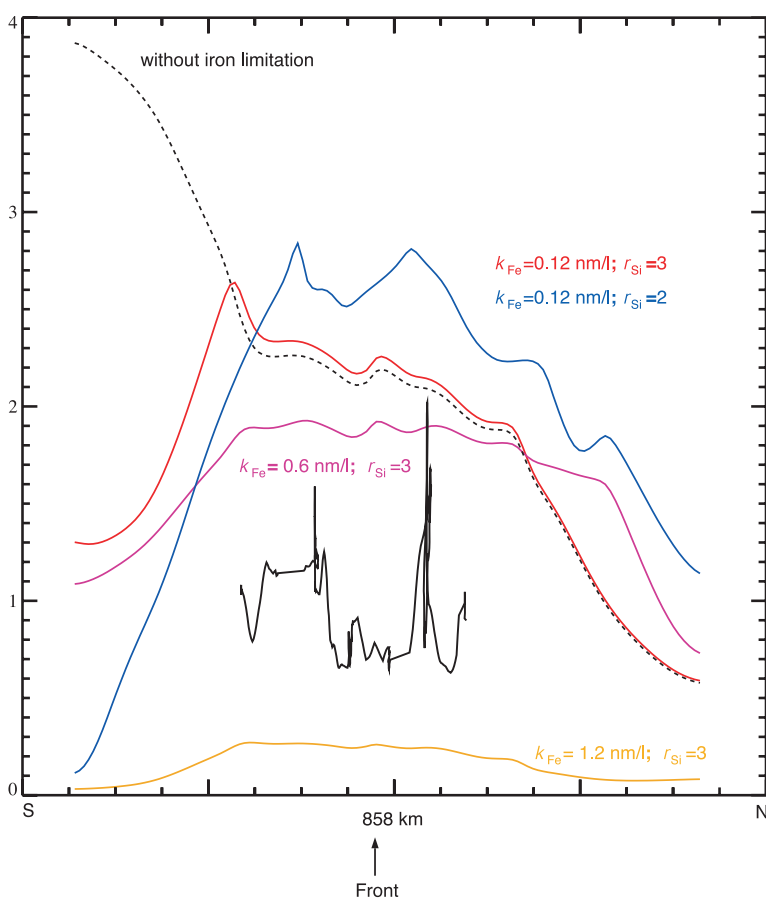

Fig. 16. Meridional transects of observed and simulated chlorophyll concentrations [ $\mu \mathrm{g} \mathrm{Chl} a / 1$ ] from different experiments. Observations (bold black line) are from November 1992 (left) and December (right) 1995. Model results are snapshots from the same time in the year. Displayed are the "no iron"-experiment (dashed line), and the iron experiments with different values for $k_{\mathrm{Fe}}$ and $r_{\mathrm{Si}}$ (coloured lines). Observed and simulated chlorophyll concentrations are centered about the location of the Antarctic Polar Front. 
pronounced increase in chlorophyll concentrations south of the front-which is not confirmed by observations.

For the 1992 data, it is obvious that results from the simulation with a fixed ratio of $r_{\mathrm{Si}}=2$ agree well with observed chlorophyll concentration. Simulated chlorophyll concentrations in the experiments with $k_{\mathrm{Fe}}=1.2 \mathrm{nmol} / 1$ and $k_{\mathrm{Fe}}=0.6 \mathrm{nmol} / 1$ are significantly lower than the observed values.

For the 1995 data, agreement with simulated chlorophyll concentrations is not as good. Compared to 1992, observed chlorophyll concentrations are significantly smaller and best agreement is achieved in the experiment with $k_{\mathrm{Fe}}=0.6 \mathrm{nmol} / \mathrm{l}$. For both datasets, however, the experiment with $k_{\mathrm{Fe}}=1.2 \mathrm{nmol} / 1$ underestimates the observed chlorophyll concentrations significantly. We thus conclude that an iron half saturation constant of $k_{\mathrm{Fe}}=1.2 \mathrm{nmol} / 1$ does not give an adequate representation of a natural diatom community.

The differences in the observed chlorophyll concentrations between both years and the differences in the best fit of simulated chlorophyll concentration raise the question of causality. First of all, differences could be explained by dominance of different diatom species. Whereas in 1992 the diatom species Corethron criophilum and Fragilariopsis kerguelensis were dominant (Bathmann et al., 1997a), in 1995/1996 the diatom species Thalassiothrix sp., Chaetoceros sp. and Pseudonitzschia sp. dominated the phytoplankton community (Klaas et al., 1997; Smetacek et al., 2002). Moreover, whereas in 1992 relatively high iron concentrations were observed prior to the development of the phytoplankton bloom, iron concentration in 1995/ 1996 was generally low (de Jong et al., 1997). Upwelling in this situation was observed to be relatively weak (Strass et al., 2002a); so the differences might well be due to variability of regional or largescale hydrography - which cannot be covered by an idealized model with fixed lateral boundary conditions.

The perhaps most striking feature of both model results and observations is the presence of two pronounced phytoplankton maxima. Especially for 1992, the position of the two simulated maxima relative to the front is well reproduced by the model. Bottom topography plays a crucial role in the formation of these patterns: Experiments with a flat bottom (not shown) feature much larger meridional excursions of the meanders and thus reveal larger fluctuations in the meridional overturning circulation. The location of overturning cells needs to be stabilized by a largescale sloping topography to produce two distinct phytoplankton maxima. A similar vertical velocity structure above the northern slope of the Atlantic Indian Ridge may be responsible for the observed double-peak plankton distribution.

\section{Discussion and conclusions}

A newly developed coupled ocean-ecosystem model in an eddy-resolving configuration for the region of the Antarctic Polar Front (APF) has been introduced. The model is based on biochemical fluxes of nitrogen and silicate and considers possible iron limitation. It is integrated for more than 2 years and is the first model which successfully simulates both mesoscale hydrography and the annual cycle of plankton growth and decay in the Antarctic Circumpolar Current (ACC) and the ambient Southern Ocean.

We have demonstrated that regional hydrodynamics strongly affects the distribution of biological tracers. Eddies and the dynamics of the meander current lead to mesoscale variability of plankton biomass and nutrients as familiar from observations in the region of the ACC (e.g. Smetacek et al., 1997; Strass et al., 2002a). Formation of isolated eddies enables the encapsulation of nutrients and plankton from different regimes and their conservation within an ambient water mass. Biological processes in an isolated eddy thus can still reflect the properties of their source region. So, to get an idea of the "history" of an ecosystem sampled during a field experiment in a region of large mesoscale variability, it appears necessary to consider hydrography as well as nutrient and plankton distribution also on a larger scale than that of the actual sampling area.

However, frontal dynamics alone cannot explain the observed enhancement of phytoplankton biomass along the APF. Although our simulation covers the cross front circulation with a reduced surface mixed layer depth in the vicinity of the Antarctic Polar Front and deep mixed layers in the ambient ACC, experiments with nutrient limitation by either nitrogen or silicate cannot reproduce the characteristic plankton 
distribution with a chlorophyll maximum near the APF and a high nutrient-low chlorophyll region further south. We conclude that deep mixed layers alone cannot explain the HNLC area in the southern ACC.

Considering possible iron limitation changes model results dramatically. Compared to the ambient regions, primary production and plankton biomass is enhanced in the vicinity of the front in all experiments including iron limitation. In contrast to Mitchell et al. (1991) who hypothesize that iron addition would not enhance phytoplankton growth in the Southern Ocean without increasing the strength of stratification, our results indicate that iron is the crucial factor limiting phytoplankton growth in the southern ACC. These findings agree with the hypotheses of several authors (e.g. Martin et al., 1990; Buma et al., 1991; de Baar et al., 1995) that the Southern Ocean HNLC area is iron limited. Ignoring iron limitation leads to an overestimation of phytoplankton biomass in that area.

Due to the uptake of iron by phytoplankton, simulated iron concentration decreases in the southern ACC and agrees well with observations in that area. So, although the initial iron concentration in the simulation is horizontally uniform, the model is able to reproduce the regional distribution in the ACC region, which indicates that ecosystem and frontal dynamics are the key mechanisms for iron redistribution in the Southern Ocean.

Our model results also indicate that the vertical transport linked to the meandering current and the cross front circulation is the prime source for iron in the ACC surface layer. In agreement with observations (Strass et al., 2002a), minima and maxima of phytoplankton concentrations in the meander current coincide with up- and downwelling zones, respectively, which seems to contradict with the generally accepted idea that upwelling leads to increased phytoplankton biomass due to 'new nutrient input'. The reason for this unexpected result is that "newly" upwelled water is rich in nutrients (specifically iron) but poor in phytoplankton. This water spreads horizontally near the surface and phytoplankton grows until water is downwelled and the phytoplankton community is moved out of the euphotic zone. This process leads to the typical mesoscale phytoplankton distribution and to the formation of maximum chlorophyll concentrations directly south of the front.
The same argument applies for the larger scale, cross-frontal circulation: Two pronounced pairs of meridional overturning cells produce an intense upwelling near the front and strong downwelling north and south of it. Again, the upwelling areas are associated with high iron, low chlorophyll concentration while two maxima of plankton concentrations are found near the downwelling areas. It thus appears that maximum plankton concentrations are not only determined by the availability of nutrients but also by the individual residence time of the plankton community in the euphotic zone. North of these overturning cells, silicate limitation inhibits phytoplankton blooms, while iron limitation is responsible for the HNLCarea in the southern ACC.

Striking is the occurrence of two phytoplankton maxima north and south of the front which also were found in observations from 1992 (Bathmann et al., 1997a) and 1995 (Hense, 1997; Bathmann et al., 1997b) in the same region. These two maxima are both associated with the APF and not induced by nearby fronts like the Sub-Antarctic Front and Southern Polar Front, which are located at roughly $45^{\circ} \mathrm{S}$ and $55^{\circ} \mathrm{S}$, respectively (Lutjeharms and Valentine, 1984; Veth et al., 1997), and thus out of the model domain. In the simulation, this double structure is caused by the formation of two pairs of overturning cells above the model representation of the northern slope of the Atlantic Indian Ridge. It cannot be found in experiments with a flat bottom where meridional overturning circulation is much less variable. We conclude that large-scale bottom topography strongly affects the cross-front circulation and may determine the meridional position of local maxima and minima of phytoplankton biomass.

Sensitivity experiments with different $\mathrm{Si} / \mathrm{N}$-uptake ratios indicate that the boundary between silicate and iron limitation shifts southward when the $\mathrm{Si} / \mathrm{N}$-uptake ratio is increased. While phytoplankton growth is limited by iron in experiments with small $\mathrm{Si} / \mathrm{N}$-uptake ratios, a higher demand for silica (per nitrogen or iron unit) for uptake ratios larger than 2 leads to an early depletion of dissolved silicate and thus to silicate limitation in most of the APF region and iron limitation only in the southern ACC. The best agreement with observations was achieved in simulations with an $\mathrm{Si} / \mathrm{N}$-uptake ratio of 2 , where during the summer the boundary between silicate limitation in the north and 
iron limitation in the south is close to the location of the Antarctic Polar Front. However, due to changes in the phytoplankton species composition, this might be subject to a large interannual variability. Some of the dominant diatom species are heavily silicified (e.g. Quéguiner et al., 1997; Hense et al., 1998); we expect that variations of their abundance influence the biogeochemical cycle and the boundary between different regimes.

As measurements of iron-dependent growth rates are scarce and subject to large uncertainties, we conducted a series of experiments with different half saturation constants for iron. Not surprisingly, phytoplankton biomass strongly decreases for increasing iron half saturation constants. Best agreement with observations is achieved with an iron half saturation constant of $0.12 \mathrm{nmol} / \mathrm{l}$; whereas using a half saturation constant of $1.2 \mathrm{nmol} / \mathrm{l}$ (Lancelot et al., 2000) leads to largely underestimated phytoplankton concentrations. We conclude that an iron half saturation constant of $1.2 \mathrm{nmol} / 1$ is too high for a natural (diatom dominated) phytoplankton community. However, reliable measurements of this parameter are still desirable.

Observation-based estimates of mesozooplankton grazing pressure in the region of the Antarctic Polar Front range between $0.3 \%$ and $3.7 \%$ of daily primary production (Dubischar and Bathmann, 1997). The grazing pressure, however, strongly depends on zooplankton composition. The occurrence of swarm organisms like salps and krill, which are not included in the model so far, can lead temporarily to a grazing pressure exceeding $100 \%$ of primary production (Dubischar and Bathmann, 1997; Pakhomov et al. 1997). In our experiments, zooplankton grazing pressure was thus rather low, not exceeding 3\% of the primary production in the 10-day mean. Thus, growth of larger phytoplankton is not primarily controlled by mesozooplankton grazing but rather by the occurrence of downwelling events and the deepening of the mixed layer in autumn.

The sensitivity experiments have shown that zooplankton biomass is strongly affected when phytoplankton growth is limited by nutrient (iron)availability. Given the high sensitivity of zooplankton concentrations to nutrient supply, it is reasonable to assume that carbon export and sedimentation of biogenic material is strongly affected by the amount of dissolved iron, e.g. by fluctuations in local iron upwelling. Observations from in vitro experiments in the Equatorial Pacific indicated a significant increase of carbon export in situations where upwelling leads to an even small increase of iron concentration in the surface layer (Coale et al., 1996), and we believe that the same holds true in the Southern Ocean.

On the other hand, nutrient (iron) availability and the strength of upwelling might not only affect primary production and plankton stock but also upper trophic levels. Observations from Ghanian coastal waters indicate that upwelling events affect zooplankton concentration and the abundance and reproduction of fish in these regions (Quaatey and Maravelias, 1999). Thus, even the high abundance of fish and seabirds in the vicinity of the Antarctic Polar Front (Tate Regan, 1914; Norman, 1938, van Franeker et al., 2002) appears to be a result of increased upwelling of nutrient rich (iron rich) water in this region.

We therefore conclude that iron limitation is a crucial point for understanding the pelagic ecosystem in the Southern Ocean. Observed enhanced phytoplankton biomass in the region of the Antarctic Polar Front can be explained by mesoscale variability resulting in regional upwelling of iron and silicate. North and south of the front, silicate or iron limitation prevents phytoplankton blooms. Minima and maxima of phytoplankton biomass are related to baroclinic instability, which in turn is influenced by the largescale bottom topography.

\section{Outlook}

Our simulations with BIMAP do not cover interannual variability of hydrography (e.g. location of the front, response to atmospheric forcing) or the ecosystem (e.g. species distribution, abundance of swarm organisms or top predators). From observations, it remains unclear whether shifts of phyto- and zooplankton species compositions can be attributed to variations in regional hydrography or represent inherent variability of the ecosystem itself. So, the introduction of further phyto- and zooplankton compartments is desirable. However, in the region of the Polar Front the "typical" distinction between diatoms as large phytoplankton and autotrophic flagellates as 
small phytoplankton does not make much sense, as diatoms clearly dominate the phytoplankton biomass. Instead, different diatom species with different demand for nutrients and different nutrient uptake ratios should be considered but - as spatial resolution is to be kept eddy-resolving - would require further increase of computing resources. To achieve a realistic representation of the different plankton compartments and the fluxes between them, further measurements of nutrient uptake for the dominant phytoplankton species are required.

\section{Acknowledgements}

Valuable discussions with R. Scharek are gratefully acknowledged. Discussions within the AWI silica group, the BRIOS group, Ch. Dieterich, and V. Strass helped to improve the manuscript. The ECMWF analysis data were received via the German Weather Service. The authors would like to thank three anonymous reviewers for their helpful comments.

\section{References}

Allanson, B.R., Parker, L.D., 1983. Frontal zones, chlorophyll and primary production patterns in the surface waters of the Southern Ocean south of Cape Town. Reports from the 5th National Oceanographic Symposium. South African Journal of Science/ Suid-Afrikaanse Tydskrif vir Wetenskap 79/4, 153-154.

Archer, D.E., Johnson, K., 2000. A model of the iron cycle in the ocean. Global Biogeochemical Cycles 14, 269-279.

Baretta, J.W., Ebenhöh, W., Ruardij, P., 1995. The European Regional Seas Ecosystem Model, a complex marine ecosystem model. Netherlands Journal of Sea Research 33/3-4, 233-246.

Bathmann, U.V., Scharek, R., Klaas, C., Dubischar, C.D., Smetacek, V., 1997a. Spring development of phytoplankton biomass and composition in major water masses of the Atlantic Sector of the Southern Ocean. Deep-Sea Research 44/1-2, 51-68.

Bathmann, U.V., Lucas, M., Smetacek, V. (Eds.), 1997b. With contributions of the participants. The expedition Antarktis XIII/1-2 of the research vessel "Polarstern" in 1995/96. Reports on Polar Research, vol. 221. Alfred Wegener Institute for Polar and Marine Research, Bremerhaven, pp. 1-136.

Beckmann, A., Hellmer, H.H., Timmermann, R., 1999. A numerical model of the Weddell Sea: large scale circulation and water mass distribution. Journal of Geophysical Research 104/C10, 23375-23391.

Belkin, I.M., Gordon, A.L., 1996. Southern Ocean fronts from the Greenwich meridian to Tasmania. Journal of Geophysical Research 101/C2, 3675-3696.
Botnikov, V.N., 1963. Geographic position of the Antarctic convergence zone in the Pacific Ocean. Soviet Antarctic Information Bulletin 4, 1827-1837.

Boyd, P.W., Watson, A.J., Law, C.S., Abraham, E.R., Trull, T., Murdoch, R., Bakker, D.C.E., Bowie, A.R., Buesseler, K.O., Chang, H., Charette, M., Croot, P., Downing, K., Zeldis, J. et al., 2000. A mesoscale phytoplankton bloom in the polar Southern Ocean stimulated by iron fertilization. Nature 407/6805, $695-702$.

Bryden, H.L., 1983. The Southern Ocean. In: Robinson, A.R. (Ed.), Eddies in Marine Science. Springer, New York, pp. 265-277.

Buma, A.G.J., de Baar, H.J.W., Nolting, R.F., van Bennekom, A.J., 1991. Metal enrichment experiments in the Weddell-Scotia Seas: effects of iron and manganese on various plankton communities. Limnology and Oceanography 36/8, 1865-1878.

Burkov, V.A., 1993. New features of the Southern Ocean hydrology. In: Voronina, N.M. (Ed.), Pelagic ecosystems of the Southern Ocean. Nauka, Moskva, pp. 5-19. SB. NAUCHN. TR. IOAN.

Chelton, D.B., Schlax, M.G., Witter, D.L., Richman, J.G., 1990. GEOSAT altimeter observations of the surface circulation of the Southern Ocean. Journal of Geophysical Research 95/C10, 17877-17903.

Coale, K.H., Fitzwater, S.E., Gordon, R.M., Johnson, K.S., Barber, R.T., 1996. Control of community growth and export production by upwelled iron in the Equatorial Pacific Ocean. Nature 379/6566, 621-624.

Cowles, T.J., Wingard, C.E., Barth, J.A., Pierce, S.D., 2000. Patterns of mesoscale variability in bio-optical properties in the Antarctic Polar Frontal zone in austral spring 1997 and summer 1998. Southern Ocean-JGOFS Symposium, Brest-F, 8-12 July, p. 62.

Dafner, E.V., Mordasova, N.V., 1994. Influence of biotic factors on the hydrochemical structure of surface water in the Polar Frontal Zone of the Atlantic Antarctic. Marine Chemistry 45, 137-148.

de Baar, H.J.W., de Jong, J.T.M., Bakker, D.C.E., Löscher, B.M., Veth, C., Bathmann, U., Smetacek, V., 1995. Importance of iron for plankton blooms and carbon dioxide drawdown in the Southern Ocean. Nature 373, 412-415.

de Jong, J.T.M., den Das, J., Timmermans, K.R., de Baar, H.J.W., 1997. Field distribution of iron in a section of the Antarctic Polar Frontal Zone. In: Bathmann, U.V., Lucas, M., Smetacek, V. (Eds.), Reports on Polar Research: The Expedition Antarktis XIII/1-2 of the Research Vessel "Polarstern" in 1995/96. Alfred Wegener Institute for Polar and Marine Research, Bremerhaven, pp. 44-52. With contributions of the participants.

Dubischar, C.D., Bathmann, U.V., 1997. Grazing impact of copepods and salps on phytoplankton in the Atlantic sector of the Southern Ocean. Deep-Sea Research 44/1-2, 415-434.

Ebenhöh, W., Kohlmeier, K., Radford, P.J., 1995. The benthic biological submodel in the European Regional Seas Ecosystem Model. Netherlands Journal of Sea Research 33 (3/4), 423-452.

Eriksen, C.C., Weller, R.A., Rudnick, D.L., Pollard, R.T., Regier, L.A., 1991. Ocean frontal variability in the Frontal Air-Sea Interaction Experiment. Special section: Frontal Air-Sea Interaction Experiment. Journal of Geophysical Research 96/C5, 8569-8591.

Fasham, M.J.R., Ducklow, H.W., McKelvie, S.M., 1990. A nitro- 
gen-based model of plankton dynamics in the oceanic mixed layer. Journal of Marine Research 48, 591-639.

Flierl, G.R., Davis, C.S., 1993. Biological effects of Gulf Stream meandering. Journal of Marine Research 51/3, 529-560.

Fransz, H.G., Gonzalez, S.R., 1997. Latitudinal metazoan plankton zones in the Antarctic Circumpolar Current along $6^{\circ} \mathrm{W}$ during austral spring 1992. Deep-Sea Research 44/1-2, 395-414.

Froneman, P.W., McQuaid, C.D., Laubscher, R.K., 1999. Size-fractionated primary production studies in the vicinity of the Subtropical Front and an adjacent warm-core eddy south of Africa in austral winter. Journal of Plankton Research 21/11, 20352109.

Gille, S.T., Stevens, D.P., Tokmakian, R.T., Heywood, K.J., 2001. Antarctic Circumpolar Current response to zonally averaged winds. Journal of Geophysical Research 106/C2, 2743-2759.

Gille, S.T., Kelly, K.A., 1996. Scales of spatial and temporal variability in the Southern Ocean. Journal of Geophysical Research 101/C4, 8759-8773.

Gordon, R.M., Johnson, K.S., Coale, K.H., 1998. The behaviour of iron and other trace elements during the IronEx-I and PlumEx experiments in the Equatorial Pacific. Deep-Sea Research 45/6, $995-1041$.

Gouretski, V.V., Danilov, A.I., 1994. Characteristics of warm rings in the African sector of the Antarctic Circumpolar Current. Deep-Sea Research 41/8, 1131-1157.

Haidvogel, D.B., Wilkin, J.L., Young, R.E., 1991. A semi-spectral primitive equation ocean circulation model using vertical sigma and orthogonal curvilinear horizontal coordinates. J. Comput. Phys. 94, 151- 185 .

Haidvogel, D.B., Beckmann, A., 1999. Numerical Ocean Circulation Modelling. Imperial College Press, London, 344 pp.

Hart, T.J., 1934. On the phytoplankton of the South-West Atlantic and the Bellingshausen Sea, 1929-1931. Discovery Reports 8, $1-268$.

Hartmann, C., Hollmann, B., Kattner, G., Richter, K.-U., Terbrüggen, A., 1997. Nutrients, Dissolved and Particulate Matter. In: Bathmann, U.V., Lucas, M., Smetacek, V. (Eds.), Reports on Polar Research: The Expedition Antarktis XIII/1-2 of the Research Vessel "Polarstern" in 1995/96. Alfred Wegener Institute for Polar and Marine Research, Bremerhaven, pp. 44-52. With contributions of the participants.

Hense, I., 1997. Chlorophyllverteilung und Phytoplanktonbiomasse in der antarktischen Polarfront. Diplomarbeit, Fachbereich Biologie/Chemie, University of Bremen. 72 pp.

Hense, I., Bathmann, U., Hartmann, C., Strass, V., Smetacek, V., 1998. Spiny phytoplankton-slowing down the carbon pump in the Southern Ocean? published as a supplement to EOS. Transactions, American Geophysical Union 79/1 (OS31C-10).

Hense, I., Bathmann, U.V., Timmermann, R., 2000. Plankton dynamics in frontal systems of the Southern Ocean. Journal of Marine Systems 27/1-3, 235-252.

Hense, I., Timmermann, R., Beckmann, A., Bathmann, U.V., 2003. Regional and interannual variability of ecosystem dynamics in the Southern Ocean. Ocean Dynamics 53, 1-10.

Hutchins, A.D., Bruland, K.W., 1998. Iron-limited diatom growth and $\mathrm{Si}: \mathrm{N}$ uptake ratios in a coastal upwelling regime. Nature $393,561-564$.
Hutchins, D.A., Franck, V.M., Brzezinski, M.A., Bruland, K.W., 1999. Inducing phytoplankton iron limitation in iron-replete coastal waters with a strong chelating ligand. Limnology and Oceanography 44/4, 1009-1018.

Ikeda, Y., Siedler, G., Zwierz, M., 1989. On the variability of Southern Ocean front locations between southern Brazil and the Antarctic Peninsula. Journal of Geophysical Research 94/ C4, 4757-4762.

Klaas, C., Kühn, S., Menden-Deuer, S., Reynarson, T., Smetacek, V., 1997. Phytoplankton and heterotrophic protist counts. In: Bathmann, U.V., Lucas, M., Smetacek, V. (Eds.), Reports on Polar Research: The Expedition Antarktis XIII/1-2 of the Research Vessel "Polarstern" in 1995/96. Alfred Wegener Institute for Polar and Marine Research, Bremerhaven, pp. 44-52. With contributions of the participants.

Kumar, N., Anderson, R.F., Mortlock, R.A., Froelich, P.N., Kubik, P., Dittrich-Hannen, B., Suter, M., 1995. Increased biological productivity and export production in the glacial Southern Ocean. Nature 378/6558, 675-680.

Laevastu, T., 1960. Factors affecting the temperature of the surface layer of the sea. Commentationes Physico-Mathematicae 25/1, $8-134$.

Lancelot, C., Hannon, E., Becquevort, S., Veth, C., de Baar, H.J.W., 2000. Modeling phytoplankton blooms and carbon export production in the Southern Ocean: dominant controls by light and iron in the Atlantic sector in Austral spring 1992. Deep-Sea Research 47/9, 1621-1662.

Löscher, B.M., de Baar, H.J.W., de Jong, J.T.M., Veth, C., Dehairs, F., 1997. The distribution of $\mathrm{Fe}$ in the Antarctic Circumpolar Current. Deep-Sea Research 44/1-2, 143-187.

Lutjeharms, J.R.E., Valentine, H.R., 1984. Southern Ocean thermal fronts south of Africa. Deep-Sea Research 31/12A, $1461-1475$.

Martin, J.H., 1990. Glacial-interglacial $\mathrm{CO}_{2}$ change: the iron hypothesis. Paleoceanography 5/1, 1-13.

Martin, J.H., Gordon, R.M., Fitzwater, S.E., 1990. Iron in Antarctic waters. Nature 345, 156-158.

Mitchell, B.G., Brody, E.A., Holm-Hansen, O., McClain, C., Bishop, J., 1991. Light limitation of phytoplankton biomass and macronutrient utilization in the Southern Ocean. Limnology and Oceanography 36/8, 1662-1677.

Moon, C.H., Yang, S.R., Yang, H.S., Cho, H.J., Lee, S.Y., Kim, S.Y., 1998. Regeneration processes of nutrients in the polar front area of the East Sea: 4. Chlorophyll $a$ distribution, new production and the vertical diffusion of nitrate. Journal of the Korean Fisheries Society 31/2, 259-266.

Morel, F.M.M., Hudson, R.J.M., Price, N.M., 1991. Limitation of productivity by trace metals in the sea. Limnology and Oceanography 36/8, $1742-1755$.

Norman, J.R., 1938. Coast fishes: Part III. The Antarctic zone. Discovery Reports 18, 1-104.

Nowlin, W.D., Klinck, J.M., 1986. The physics of the Antarctic Circumpolar Current. Reviews of Geophysics 24/3, 469-491.

Onken, R., 1992. Mesoscale upwelling and density finestructure in the seasonal thermocline - a dynamical model. Journal of Physical Oceanography 22/11, 1257-1273.

Oschlies, A., Garçon, V., 1998. Eddy-induced enhancement of pri- 
mary production in a model of the North Atlantic Ocean. Nature 394/6690, 266-269.

Oschlies, A., Garçon, V., 1999. An eddy-permitting coupled physical-biological model of the North Atlantic: 1. Sensitivity to advection numerics and mixed layer physics. Global Biogeochemical Cycles 13/1, 135-160.

Pacanowski, R.C., Philander, S.G.H., 1986. A model of the seasonal cycle in the tropical Atlantic Ocean. Journal of Geophysical Research 91, 14192-14206.

Parkinson, C.L., Washington, W.M., 1979. A large-scale numerical model of sea ice. Journal of Geophysical Research 84/C1, 311-337.

Pakhomov, E.A., Verheye, H.M., Atkinson, A., Laubscher, R.K., Taunton-Clark, J., 1997. Structure and grazing impact of the mesozooplankton community during late summer 1994 near South Georgia, Antarctica. Polar Biology 18/3, 180-192.

Pingree, R.D., Holligan, P.M., Mardell, G.T., 1979. Phytoplankton growth and cyclonic eddies. Nature 278, 245-247.

Pollard, R.T., Regier, L.A., 1992. Vorticity and vertical circulation at an ocean front. Journal of Physical Oceanography 22/6, 609-625.

Pondaven, P., Fravalo, C., Ruiz-Pino, D., Tréguer, P., Quéguiner, B., Jeandel, C., 1998. Modelling the silica pump in the Permanently Open Ocean Zone of the Southern Ocean. Journal of Marine Systems 17, 587-619.

Quaatey, S.N.K., Maravelias, C.D., 1999. Maturity and spawning pattern of Sardinella aurita in relation to water temperature and zooplankton abundance off Ghana, West Africa. Journal of Applied Ichthyology 15/2, 63-69.

Quéguiner, B., Tréguer, P., Peeken, I., Scharek, R., 1997. Biogeochemical dynamics and the silicon cycle in the Atlantic sector of the Southern Ocean during Austral spring 1992. Deep-Sea Research 44/2, 69-90.

Sakshaug, E., Holm-Hansen, O., 1984. Factors governing pelagic production in polar oceans. In: Holm-Hansen, O., Bolis, L., Gilles, R. (Eds.), Marine Phytoplankton and Productivity. Lecture Notes on Coastal and Estuarine Studies, vol. 8. Springer Verlag, Berlin, pp. 1-18.

Scharek, R., Van Leeuwe, M.A., De Baar, H.J.W., 1997. Responses of Southern Ocean phytoplankton to the addition of trace metals. Deep-Sea Research 44/1-2, 209-227.

Shiomoto, A., Ishii, H., 1995. Distribution of biogenic silica and particulate organic matter in coastal and oceanic surface waters off the South Shetland Islands in summer. Polar Biology 15, 105-113.

Six, K.D., Maier-Reimer, E., 1996. Effects of plankton dynamics on seasonal carbon fluxes in an ocean general circulation model. Global Biogeochemical Cycles 10/4, 559-583.

Smetacek, V., de Baar, H.J.W., Bathmann, U.V., Lochte, K., Rutgers van der Loeff, M.M., 1997. Ecology and biogeochemistry of the Antarctic Circumpolar Current during austral spring: a summary of Southern Ocean JGOFS cruise ANT X/6 of R.V. Polarstern. Deep-Sea Research 44/1-2, 1-21.

Smetacek, V., Klaas, C., Menden-Deuer, S., Rynearson, T.A., 2002. Mesoscale distribution of dominant diatom species relative to the hydrographical field along the Antarctic Polar Front. DeepSea Research 49/18, 3835-3848.
Smith, W.O., Nelson, D.M., 1985. Phytoplankton bloom produced by a receding ice edge in the Ross Sea: spatial coherence with the density field. Science (Washington) 227/4683, 163-166.

Smith, N.R., Fandry, C.B., 1978. Combined effects of wind stress and topography in a two-layer model of the Southern Ocean. Deep-Sea Research 25/4, 371-390.

Smith, W.H.F., Sandwell, D.T., 1997. Global sea floor topography from satellite altimetry and ship depth soundings. Science 277 , 1956-1962.

Spall, S.A., Richards, K.J., 2000. A numerical model of mesoscale frontal instabilities and plankton dynamics: I. Model formulation and initial experiments. Deep-Sea Research 47/7, 1261-1301.

Stramski, D., Reynolds, R.A., Kahru, M., Mitchell, B.G., 1999. Estimation of particulate organic carbon in the ocean from satellite remote sensing. Science (Washington) 285/5425, $239-242$.

Strass, V.H., 1994. Mesoscale instability and upwelling: Part 2. Testing the diagnostics of vertical motion with a three-dimensional ocean front model. Journal of Physical Oceanography 24/ 8, 1759- 1767.

Strass, V.H., Naveira Garabato, A.C., Pollard, R.T., Fischer, H.I., Hense, I., Allen, J.T., Read, J.F., Leach, H., Smetacek, V., 2002a. Mesoscale Frontal Dynamics: shaping the environment of primary production in the Antarctic Circumpolar Current. Deep-Sea Research 49/18, 3735-3769.

Strass, V.H., Naveira Garabato, A.C., Bracher, A.U., Pollard, R.T., Lucas, M.I., 2002b. A 3-D mesoscale map of primary production at the Antarctic Polar Front: results of a diagnostic model. Deep-Sea Research 49/18, 3813-3834.

Sullivan, C.W., Arrigo, K.R., McClain, C.R., Comiso, J.C., Firestone, J., 1993. Distributions of phytoplankton blooms in the Southern Ocean. Science (Washington) 262/5141, 1832-1837.

Takeda, S., 1998. Influence of iron variability on nutrient consumption ratio of diatoms in oceanic waters. Nature 393, 774-777.

Tate Regan, C., 1914. British Antarctic (Terra Nova) Expedition 1910, fishes. Terra Nova Reports Zoology 1, 125-156.

Timmermann, R., Beckmann, A., Hellmer, H.H., 2002. Simulation of ice-ocean dynamics in the Weddell Sea: Part I. Model description and validation. Journal of Geophysical Research, 107/ C3, 10.1029/2000JC00074.

Trathan, P.N., Brandon, M.A., Murphy, E.J., 1997. Characterization of the Antarctic Polar Frontal Zone to the north of South Georgia in summer 1994. Journal of Geophysical Research 102/C5, 10483-10497.

Tréguer, J., Jacques, G., 1992. Dynamics of nutrients and phytoplankton, and fluxes of carbon, nitrogen and silicon in the Antarctic Ocean. Polar Biology 12, 149-162.

van Franeker, J.A., van den Brink, N.W., Bathmann, U.V., Pollard, R.T., de Baar, H.J.W., Wolff, W.J., 2002. Responses of seabirds, in particular prions (Pachyptila sp.), to small-scale processes in the Antarctic Polar Front. Deep-Sea Research 49/18, 39313950.

Veth, C., Peeken, I., Scharek, R., 1997. Physical anatomy of fronts and surface waters in the ACC near the $6^{\circ} \mathrm{W}$ meridian during austral spring 1992. Deep-Sea Research 44/1-2, 23-50.

Wearn, R.B., Baker, J., 1981. Relation of ocean currents to wind in 
the Southern Hemisphere. Climate Diagnostics Workshop, Proceedings, Mar., 5th ed., pp. 264-267.

WOCE Hydrographic Program Office, 1998. http://oceanic.cms. udel.edu/woce/, http:/www.dkrz.de/u241046/SACserver/ SACHome.htm.

Wyrtki, K., 1960. The Antarctic convergence and divergence. Nature 187/4737, 581-582.

Zettler, E.R., Olsen, R.J., Binder, B.J., Chisholm, S.W., Fitzwater, S.E., Gordon, R.M., 1996. Iron-enrichment bottle experiments in the Equatorial Pacific: responses of individual phytoplankton cells. Deep-Sea Research 43/4-6, 1017-1029.

Zhuang, G., Zhen, Y., Duce, R.A., Brown, P.R., 1992. Link between iron and sulphur cycles suggested by detection of $\mathrm{Fe}$ (II) in remote marine aerosols. Nature 355/6360, 537-539.

Zillmann, J.W., 1972. A study of some aspects of the radiation and heat budgets of the southern hemisphere oceans. Meteorological Study, vol. 26. Bureau of Meteorology, Dept. of the Interior, Canberra, Australia, 526 pp. 